\title{
Argonne
}

ANL-21/03

\section{Assessing Climate Risks to Midwest Infrastructure Workshop}

\author{
Environmental Science Division
}




\section{About Argonne National Laboratory}

Argonne is a U.S. Department of Energy laboratory managed by UChicago Argonne, LLC under contract DE-AC02-06CH11357. The Laboratory's main facility is outside Chicago, at 9700 South Cass Avenue, Lemont, Illinois 60439. For information about Argonne and its pioneering science and technology programs, see www.anl.gov.

\section{DOCUMENT AVAILABILITY}

Online Access: U.S. Department of Energy (DOE) reports produced after 1991 and a growing number of pre-1991 documents are available free at OSTI.GOV (http://www.osti.gov/),

a service of the US Dept. of Energy's Office of Scientific and Technical Information.

Reports not in digital format may be purchased by the public from the National Technical Information Service (NTIS):

U.S. Department of Commerce

National Technical Information Service

5301 Shawnee Road

Alexandria, VA22312

www.ntis.gov

Phone: (800) 553-NTIS (6847) or (703) 605-6000

Fax: (703) 605-6900

Email: orders@ntis.gov

Reports not in digital format are available to DOE and DOE contractors from the Office of Scientific and Technical Information (OSTI):

U.S. Department of Energy

Office of Scientific and Technical Information

P.O. Box 62

Oak Ridge, TN 37831-0062

www.osti.gov

Phone: (865) 576-8401

Fax: (865) 576-5728

Email: reports@osti.gov

\section{Disclaimer}

This report was prepared as an account of work sponsored by an agency of the United States Government. Neither the United States Government nor any agency thereof, nor UChicago Argonne, LLC, nor any of their employees or officers, makes any warranty, express or implied, or assumes any legal liability or responsibility for the accuracy, completeness, or usefulness of any information, apparatus, product, or process disclosed, or represents that its use would not infringe privately owned rights. Reference herein to any specific commercial product, process, or service by trade name, trademark, manufacturer, or otherwise, does not necessarily constitute or imply its endorsement, recommendation, or favoring by the United States Government or any agency thereof. The views and opinions of document authors expressed herein do not necessarily state or reflect those of the United States Government or any agency thereof, Argonne National Laboratory, or UChicago Argonne, LLC. 
ANL-21/03

\section{Assessing Climate Risks to Midwest Infrastructure Workshop}

by

Rao Kotamarthi and Cristina Negri

Environmental Science Division, Argonne National Laboratory

Robin Graham

Computing, Environment and Life Sciences, Argonne National Laboratory

Thomas Wall

Decision \& Infrastructure Sciences Division, Argonne National Laboratory

April 2021 
This page left intentionally blank. 


\section{ACKNOWLEDGEMENTS}

The authors and workshop organizers gratefully acknowledge Argonne National Laboratory's

Program Development support and the tireless efforts of Sarah Fisk and Sarah Lightfoot of Community at Work for the excellent facilitation of this workshop and its planning. 


\section{CONTENTS}

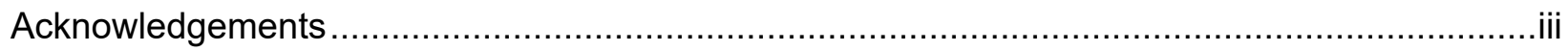

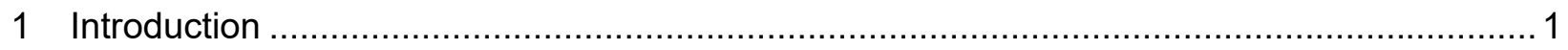

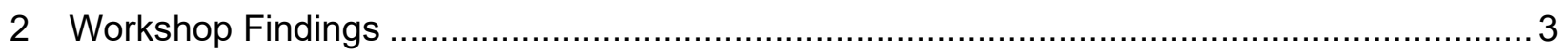

2.1 General Concerns of Practitioners and Scientists ............................................ 3

2.2 Concerns about Hazard Types and Impacts ....................................................... 5

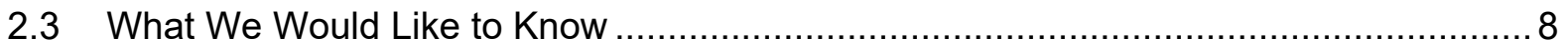

2.4 Scenario Planning ....................................................................................... 10

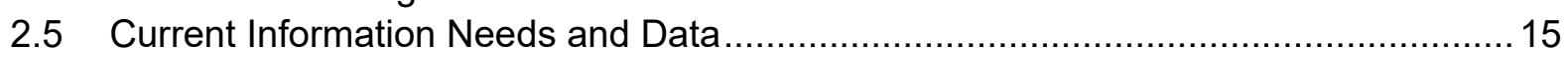

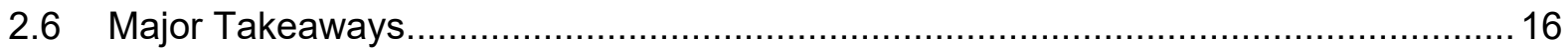

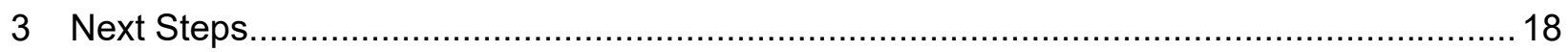

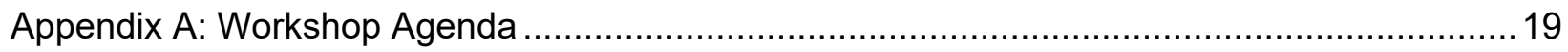

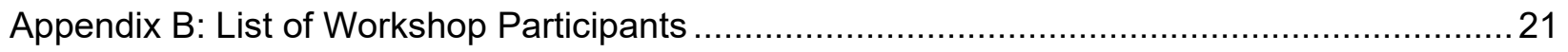

Appendix C: Rao Kotamarthi Workshop Presentation ............................................... 22

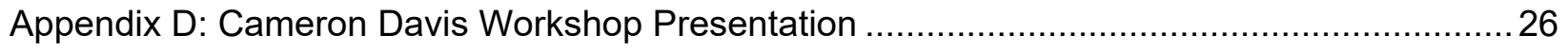

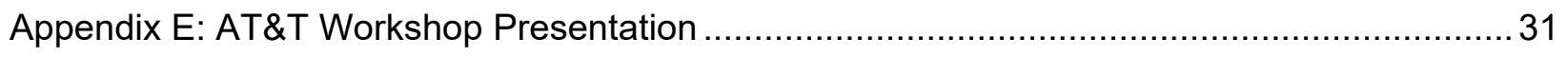

Appendix F: Concerns Discussed during Brainstorming Sessions ................................. 38

\section{FIGURES}

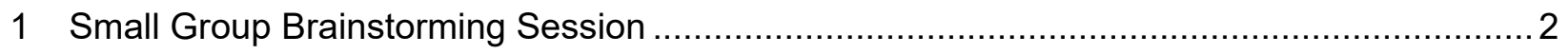

2 Cities Must Learn to Adapt to Higher Temperatures............................................ 10

3 Urban Flooding Is a Future Risk with More Intense Storms..................................... 12

4 Extreme Storms Pose Risks to Infrastructure and Crops..................................... 14 


\section{TABLES}

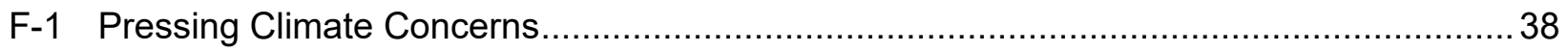

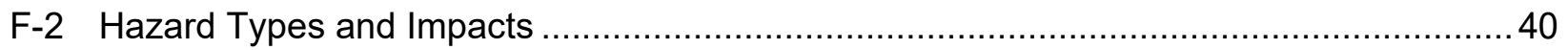

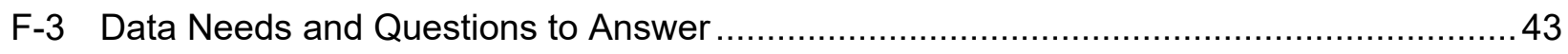

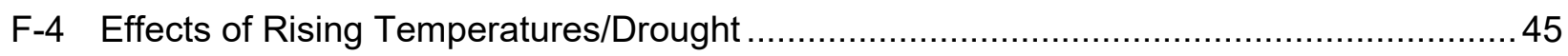

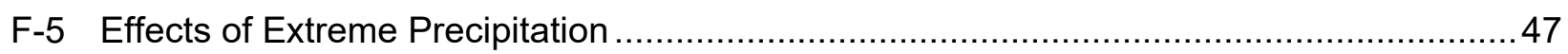

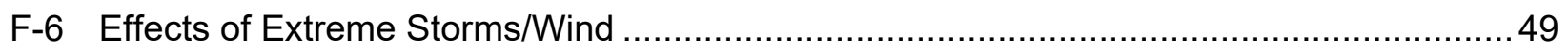

F-7 Information Needs Identified by Workshop Participants ......................................52 


\section{INTRODUCTION}

Stakeholders in industry, agriculture, and city governments are struggling to understand how to manage climate change risks. Climate scientists, meanwhile, want to know what specific information their fellow citizens need from them to take action.

On July 25-26, 2019, Argonne National Laboratory brought a group of representatives from energy industries, agriculture, and city governments together with climate change and risk researchers from across the Midwest to discuss how best to assess climate change risks to infrastructure and services (see Appendix B for list of participants).

The workshop loosely focused on climate risk and resilience in the Midwestern United States because of Argonne's location in Illinois and local partnerships and the sense that more focus was needed on this region. That is, the coastal and arctic regions of the United States were already receiving some level of attention.

The workshop had four clear goals:

1. We wanted to understand the specific climate changes that that were of most concern to the Midwest energy industry, agricultural industry, cities, and towns. What aspects of climate change kept them up at night, and why?

2. We wanted to understand what types of information these stakeholders need to prepare their institutions for climate change. Did they need climate projections to the year 2100? Did they need daily projections? What spatial scales would be most useful? What ancillary information did they need? We also wanted to understand what information they already had and what information they were lacking.

\section{Workshop Goals}

- Understand the specific practical climate change challenges that energy industries, agriculture and cities face in the Midwest

- Identify informational needs and gaps that prevent development of effective approaches to manage climate change risk

- Explore the specific research and data needed to fill information gaps

- Build relationships and learn from each other, paving the way to effective resilience and risk-management plans

3. We also wanted to understand what research will be needed to address the information gaps that stakeholders encounter. Such gaps can hinder institutions' risk management; filling these gaps can help them better understand and prepare for potential risks. Understanding these gaps can also provide important and focused research directions.

4. Finally, we hoped researchers and practitioners would connect and build relationships to better foster the creation and future sharing of information. We hoped that these relationships would enhance understanding of the region, and that the information shared would help institutions develop and improve their resilience and riskmanagement plans. 
To achieve the workshop goals, the workshop was designed to free the participants to brainstorm climate concerns, as well as research gaps and "out of the box" solutions. Designated listeners and notetakers captured the structured conversation and a professional facilitator kept the conversation on track (Figure 1).

Although the workshop did have three speakers (see Appendices C-E for presentation slides), it intentionally avoided the more common "sage on a stage" research workshop format. It was the desire of the Argonne organizers to go beyond the research community and learn from and

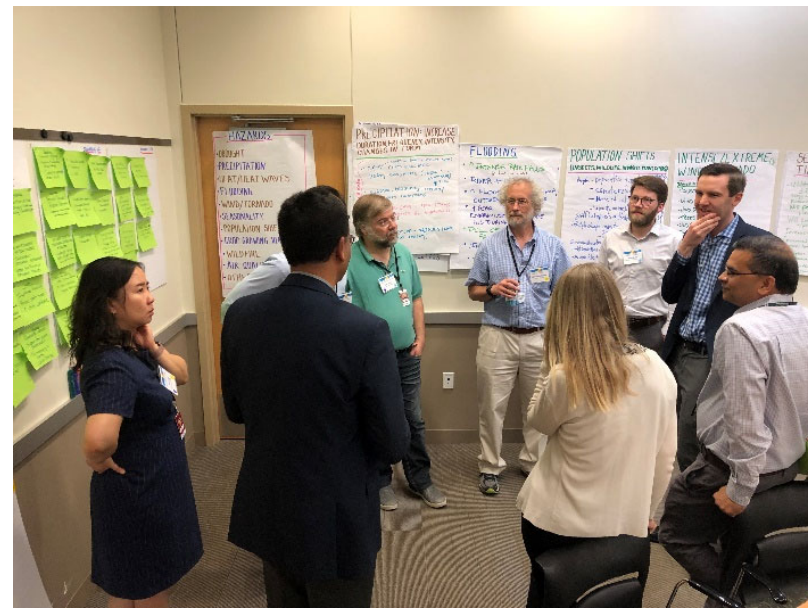

FIGURE 1 Small Group Brainstorming Session understand the information needs of practitioners who are struggling to proactively prepare their Midwest institutions for climate change. The three speakers who spoke at various times over the two-day workshop set the stage for the discussion that followed.

The workshop also asked the participants to role play (acting as the manager of a city, or an energy company executive) to address three future climate scenarios for the Midwest, and to consider how each scenario would affect either city government responsibilities or energy industry actions. Finally, the participants identified information needs and the degree to which the information needed was available or required new research.

This report documents the workshop and its findings. It ends with the workshop's recommendation to develop a Midwest consortium on climate change and risk-related research to formalize the collaboration of research institutions and governmental and industry partners who wish to engage to enable a more resilient energy and environmental future.

\section{Speakers}

- Dr. Rao Kotamarthi (atmospheric science researcher at Argonne) opened the workshop by addressing current global-to-local climate projections.

- Mr. Cameron Davis (lawyer, environmental policy expert, and elected commissioner of the Metropolitan Water Reclamation District of Greater Chicago) discussed resilient decision-making systems for tackling climate change risks drawing upon the successful Great Lakes Restoration Initiative established in 2010 with numerous federal agencies.

- Mr. Antoine Diffloth (Director of Data Insights at AT\&T) discussed his company's efforts in collaboration with Argonne to assess AT\&T's climate resilience. 


\section{WORKSHOP FINDINGS}

\subsection{GENERAL CONCERNS OF PRACTITIONERS AND SCIENTISTS}

Rao Kotamarthi kicked off the workshop by briefly reviewing some of the regional changes in climate that have been predicted and discussing uncertainty in model predictions (Appendix D). He noted how users of climate predictions may have different needs with regard to uncertainty and that managers responsible for building resilience into their systems may well need scientists to provide larger uncertainty bounds. He also noted that projection information is needed at the point and scale of action, and that scientists need to understand from practitioners what scales are meaningful for their challenges.

Because responding to climate change has social and political dimensions as well as technical and organizational dimensions, we then started discussions by asking the participants to address their general concerns before we delved into specific challenges relevant to their institutional roles (Appendix F, Table F-1).

Many workshop participants asked the question, "Are we too late?" They indicated that the lack of political will to change and the difficulty of bridging political divides were barriers to rapid change. Current regulations (as well as new ones) often have competing priorities that can be difficult to navigate. Likewise, the participants were concerned about the lack of public willingness to invest in solutions. They felt that many people do not understand the scope of the problem, which makes it difficult to communicate the need for change.

Some additional concerns included the ability to adapt to irreversible sea-level rise, translating data into action, and dealing with the interactions between factors such as climate, population growth, and economics. Participants worried that as climate change becomes a reality it is proving models correct.

The workshop identified several geopolitical concerns. These include disproportionate effects on vulnerable human populations and climate-induced migrations and conflicts caused by climate change at both regional and global scales, and different cultural and behavioral responses to climate change.

Climate change may alter a region's ability to produce food. Several participants noted that social science data would be needed to support agricultural decision-making over multiple time scales.

If natural environments are unable to adapt fast enough to mitigate changes, this may have persistent effects on biodiversity. This, in turn, may have secondary effects on disease, insects, and human migration. Participants also noted that varying abilities to balance adaptability with persistence of locally relevant genotypes may affect species prevalence relative to one another. Some specialized ecosystems, such as estuaries, may have "no place to go."

Workshop participants said that climate change may mean that small communities will be brought into closer contact with others, both regionally and globally. There will be regional differences in the types of change these communities experience, which may also be driven and exacerbated by socioeconomic disparities. Participants suggested that educating and empowering communities to deal with these changes will be key. 


\section{Key Concerns}

\section{Political Arena}

All participants expressed concern that many people do not understand climate change well, and that this causes a lack of political and public will to tackle the causes or to address mitigation and adaptation. They noted that there is a lack of consensus on how to direct investments to protect the future, and that balancing stakeholder needs with limited resources is challenging.

\section{Communication}

The topic of communication was raised by nearly all participants, in multiple dimensions. How does one frame arguments to convince policy makers? How does one communicate ranges of responses and uncertainties in a manner that is useful to those responsible for planning? How does one reconcile what climate scientists report with what designers and engineers need?

\section{Complexity}

Climate, population growth, and economics have intersecting trajectories, and our understanding of their feedbacks and drivers need to be integrated. The Midwest will be affected by both national and global issues such as cultural and behavioral differences in responses to climate change events, and the likelihood of human migration and conflicts as a result of climate change.

Participants argued that future climate change made an even stronger case to protect water quantity and quality, because both may worsen due to climate change. They highlighted the need for better regulation of current and emerging pollutants such as per- and polyfluoroalkyl substances (PFASs) in water and in biosolids.

Workshop participants indicated that they had concerns around modeling and measuring the impacts of increased precipitation, air quality, and severe weather events on daily life and health. They worried about higher power demands from communities and needing increased regulation for stormwater discharges. From an agricultural perspective, participants worried about soil loss and soil management; the magnitude of soil loss in the case of extreme and potentially multiple simultaneous extreme weather events could be disastrous.

Participants noted that modeling tools and skills are not currently keeping up with the physical events that are occurring, that it can be difficult to understand the subtleties that climate models can reveal, and that it may even be impossible to find the right data to use for predictions.

Workshop participants noted that the tone of communication around climate change is crucial; it is both important and difficult to convey urgency without causing the listener to dismiss the problem, despair, or shut down. Sensitivities around the term "climate change" mean that sometimes the discussion is avoided entirely.

Participants asked when short-term climate information could become available and useful. They were interested in understanding how to frame arguments to better convey them to policymakers, and they recognized that there is a need to better explain both problems and the implications of those problems. It is often difficult to communicate ranges and uncertainties (as opposed to concrete numbers) to the people who handle planning and response. Participants also noted that they need better ways to communicate the issues to others so that the listeners 
understand the points being made without (and outside of) any party's political agenda. They felt that people need to value this knowledge and educate themselves.

Workshop participants wanted to understand how to communicate needed information to very different audiences. For example, they want to both help the general public understand climate change, and to provide data from climate reports in a format that designers and engineers can actually use.

Participants wanted to better understand how to adapt and increase resilience in the face of increasing temperatures, system outages caused by extreme temperatures or extreme weather events, increased pressure on grid cooling infrastructure from greater air conditioning needs, and exposure of infrastructure to extreme temperatures and extreme weather events. They noted that infrastructure is often not designed to handle extreme events.

Workshop participants observed that many existing or proposed solutions are very energy intensive, and wanted to know whether current infrastructure can handle the expected peak energy loads. They noted that they would also like to understand how electricity needs in communities will change over time.

Workshop participants described a lack of consensus about how to direct investments to protect the future, and how to balance long-term versus short-term responses to extreme events. There are competing funding priorities, a need to better understand risks, and a need to reconcile different responses to risk calculations.

In addition, participants noted that it can be difficult for business models to balance stakeholder needs and limited resources. It can also be difficult_-but important—-to design a system that is robust under projected calculations.

\subsection{CONCERNS ABOUT HAZARD TYPES AND IMPACTS}

After airing their general concerns, the participants were asked to address, in the context of their professional responsibilities (agriculture, cities, energy), their concerns relative to ten climate hazards the Midwest will face. Table F-2 in Appendix F provides a list of all the concerns that were raised.

Heat and heatwaves could increase electric load because demand for air conditioning would increase in locations such as homes and workplaces. This, in turn, could degrade power lines and transformers, and possibly even cause power outages or curtailments. People would not be able to do as much outdoors. The ability of outdoor workers to respond would decrease, because the intensity and duration of the work they are able to carry out would both decrease. Outdoor recreation would also decrease for similar reasons. There

\section{Climate Hazards}

1. Heat and heatwaves

2. Drought-increases in duration and/or frequency

3. Precipitation-increases in duration, frequency, or intensity, and/or changes in form

4. Flooding

5. Wind and tornadoes

6. Wildfire

7. Crop growing viability

8. Seasonality-changes in onset and duration

9. Air and water quality

10. Human population shifts 
would be health impacts on vulnerable populations. Groups such as the very young, the very old, those with chronic illness, and those with low income would be disproportionately affected. Violence and unrest could increase. All of these factors could mean that hospitals are overtaxed when responding to human health impacts from heat and heatwaves.

Heat creates thermal stress on infrastructure. Some common results of this can include roads buckling, planes being grounded, and railways being damaged. More frequent and/or intense heat waves may necessitate changes in building design requirements. Workshop participants identified a need to recognize what constitutes a heat wave or triggers a need to respond; this may vary by sector and may have different spatial and temporal scales. They also identified a need to recognize local variation in neighborhoods' ability to mitigate heat and heatwaves.

Extreme cold (e.g., polar vortex events) could have many negative impacts. Some of those discussed by participants include impacts on wind turbines, trees, utility crew response, and perennial vegetation; problems for utility customers; income and customer differential impacts; and ground expansion impacts on equipment and saturated soils.

An increase in drought duration and/or frequency could mean that there is not enough water for households, power generation, hydropower, or industrial manufacturing. Drought concentrates waste, increasing odors and corrosion. It could impact both domestic and wild animals, the food supply, and barge transportation of goods. The Midwest is largely unprepared to reuse water. Drought may increase the pressure to increase irrigation for farming, because there is a lack of drought-tolerant crops. Both annual and perennial crops are at risk. Water quality may diminish, and aquifers may draw down. The area may be more vulnerable to increased wind erosion during drought periods. In addition, compounded events (such as wet periods followed by dry periods) may increase the frequency of wildfires. Government agencies may be unable to mount an effective response to these compound events.

Changes in precipitation and precipitation patterns other than drought can also have impacts. Heavy snowstorms could increase snow removal costs, create supply chain problems for fuel and de-icing salt, decrease city revenue by limiting tourism and conventions, increase roof and other property repairs, and necessitate changes in how we design roofs to withstand extreme snow accumulation. An increase in the number of freeze-thaw cycles would decrease the lifespan of materials and infrastructure. Increased humidity could promote airborne disease in built environments, increase power use in the summer, increase plant disease, and increase human vulnerability to heat. Increased ice storms could negatively affect power, transportation, and infrastructure. Increased hail could increase damage to crops and infrastructure.

Flooding can have profound effects on many sectors. For example, agriculture is extremely vulnerable to flooding. Floods delay the use of farm equipment to conduct activities such as planting and harvesting. They can also damage or kill crops that are already growing. Floods can also damage the water supply, increase water pollution, and impact both drinking water supplies and water treatment plants. They also cause public health issues due to the overflow of sewage. Increases in insurance losses due to flooding can increase insurance rates.

Flooding in some locations can have cascading impacts. For example, basement flooding can increase fire hazards because fire pumps are often located in basements. Flooding in industrial areas can release toxic chemicals. If emergency vehicles need to avoid flooded areas, this can increase emergency response times. Workshop participants noted that they would like to better understand how to consider energy infrastructure and stormwater management in the context of flooding. Regulations and industry standards need to be based on future conditions, not historic 
conditions. Stormwater infrastructure in the Midwest is known for being insufficient to handle even current intense storms.

Increased winds can impact air traffic and passengers. If the frequency of tornadoes increases, building codes may also need to change. Increased wind loads can cause building energy consumption to increase as well. The combined impacts of wind plus ice storms could increase damage to trees and infrastructure. Increased wind also increases the risk of fire. Wind damage can disrupt communication infrastructure, impeding emergency response.

There is a lack of specific information about historical tornadoes, severe weather, and their impacts. For example, the ways in which urban infrastructure relates to extreme wind are not well understood. There is a lack of good information on projections about hurricane and tornado intensity and frequency. This makes it hard to project future costs, or justify proactive investment.

Wildfires can destroy transmission lines. The risk of wildfire can also increase the potential for power outages, and deter the construction of alternative energy systems. They also increase risks to animals, plants, and human life, health, and mental health due to trauma, poor air quality, and damaged infrastructure of all types. Smoke associated with wildfire can decrease air quality, contaminate equipment, decrease solar photovoltaic (PV) output, and impact visibility and therefore transportation. Insurance companies are challenged to price correctly in wildfireprone regions, given the dynamic conditions. It is difficult to coordinate between multiple agencies.

The lack of crop diversity in the Midwest increases risks associated with climate change. There is potential for seasonal shift mismatches. The soil microclimate will change, and the advantage of farming the fertile, productive soils of the corn belt may be decreased by a less favorable climate. More robust invasive species may be favored, and both pests and diseases may change due to rising temperatures and humidity. In urban settings, the ability to farm outdoors in urban environments may decrease due to the effect of heat on laborers.

Changes in seasonality have disparate effects. Peak electrical loads may change from summer to winter via electrification, thereby altering the balance of use between electricity and natural gas. Utilities have different risks in different seasons, but changes in seasonality affect all farm operations. Changes in seasonality also impact insect abundance and animal behavior, as well as municipal operations and equipment repair. On the human health front, novel diseases (such as Zika) may increase, and well-known ones (such as malaria and West Nile) may shift with changes in vector and host species dynamics.

Workshop participants noted that there is a need for coupled air quality and climate models, and that the benefits from shifts from fossil-based energy to solar or wind by reducing $\mathrm{NO}_{\mathrm{x}}$ emissions and allergens need to be better explored. Ozone may increase as the temperature rises, and air contaminant chemistry may change with increased heat.

The Midwest could experience population growth due to "climate refugees" from the south or the coasts or fire-prone areas. This could have impacts on taxes, infrastructure needs, municipal services, and regional politics and governance. Current population growth projections (and concomitant planning) do not include climate refugees or lifestyle changes due to climate change. Changes in climate will affect industry location in unique and specific ways. For example, datacenters are not allowed by code to be located in 100-year floodplains. Regionally, participants noted that the impact of the Great Lakes on meteorology is not well represented in 
Earth system models; hence uncertainties in understanding the bidirectional relationships may be higher than desired.

Workshop participants noted several other concerns, including needs for coordination across sectors to ensure efficiency and avoid redundancies/islands of resilience; needs to consider regulatory-driven consequences and meeting financial constraints; and a need to consider centralized versus localized resilience (e.g., whether distributed energy gives more resilience to weather extremes).

\subsection{WHAT WE WOULD LIKE TO KNOW}

After the deep dive into climate hazards and their perceived impact on agriculture, cities and the energy industry, the participants shifted towards identifying information needs, the heart of the workshop. To begin this discussion, Cam Davis presented his thoughts on resilient decisionmaking systems for tackling climate change risks (Appendix D). Drawing on his experience with the successful Great Lakes Restoration Initiative established in 2010, he argued that just as biodiversity enhances ecosystem resilience, diverse teams with differing perspectives will create the most effective and politically and technically robust solutions for dealing with climate change. The workshop participants then reflected on what they had heard and outlined their concerns and information needs with regards creating robust decision-making systems (Appendix F, Table F-3).

Workshop participants had a number of social and political questions. These included: If there is "no new normal" and we will be experiencing continuous change, how do we plan for the future? Will climate trends just continue onward in one direction, or will they fluctuate and/or change direction repeatedly? How do we quantify resilience? How does one measure success? They noted that they currently lack the ability to bring different stakeholders to the decision table, which affects their ability to discover scenarios where everyone wins.

At-risk groups (elderly, disabled, etc.) and environmental justice communities need to have a place at the decision table (e.g., so that decisions take into account their specific needs and exposures - such as Chicago heatwaves), and decisionmakers need a system to evaluate the potential impacts of hypothesized actions. Workshop participants asked whether they could create an interactive resource to convene stakeholders and identify a process to ensure resilience decisions are effective and equitable.

Participants also wondered how to motivate people to action, and how to convince decisionmakers to allocate funds for integrated climate research. Current funders are siloed and rarely interact, they noted.

Another overarching concern during the discussion was whether the privatization of climate analysis would have negative effects on data collection and sharing. Addressing the gaps and barriers between science studies, scientists, real-world decisionmakers, and industry and policy stakeholders was seen as key. Participants noted that decisionmakers (e.g., utilities) are very important, and asked how to best provide information on extreme events to those decisionmakers and industry partners. They wanted to know what model predictions link to business decisions, and what useful metrics are for planning. Examples of known, useful metrics were mentioned, such as "annual maximum daily precipitation" and "7-day maximum flow." 
During this part of the discussion, workshop participants asked how to use probability-based information (from scientists) to give engineers concrete answers they want, while still expressing change and risk in truthful but easy-to-understand terms. They wanted to better understand how to turn climate predictions into actionable information (e.g., data that will help engineering design). The climate modelers in the room stated that they need to understand what information different sectors need to be able to tailor experiments to meet these needs. Scientists need to better understand how people use this data in the real world.

Workshop participants noted that standardization of data, codes, and methods is important for decisionmakers. They asked: Can we create a methodology to update standards using climate projections? Standardization of mandates, data, models used, and/or regulations would build public support and make sense to members of the public; it would enable data to be provided in dashboards that the public could understand; help convey urgency of action, which is currently difficult to communicate because of the lack of standardization; provide decisionmakers a common framework; help in understanding the business value proposition; and help in portfolio management. Moreover, standardization of models could pave the way to the projection of interconnected vulnerabilities.

Workshop participants agreed that data availability is critical. For example, climate data and projections need to be accessible to those who forecast energy loads for buildings.

Accessible climate data and projections would enable facility operations to address trends and capital investments, and would support more sophisticated analyses and business models. They argued that we need userfriendly climate change models that are available to all, and that information needs to be available on these models' biases and confidence levels.

Likewise, building energy usage data is not generally accessible; this hampers understanding how climate affects energy usage and how building design modifies that

\section{Benefits of Standardizing Data and Regulations}

- Builds public support for change because standards make sense to the public

- Enables creation of dashboard information that is easily understood

- Conveys the urgency of action

- Provides diverse decisionmakers with a common framework

- Assists in understanding business value propositions

- Facilitates portfolio management usage. Participants suggested creating an open-source data portal on public building energy usage so researchers and engineers can better understand and predict the climate impacts of building energy usage.

Workshop participants identified several data needs related to wind and tornadoes. These include the need for reliable wind projections for wind energy and to develop building standards that provide resiliency under future wind loads. Wind variables that are needed include the frequency, duration, and speed of wind gusts; wind direction; wind at heights of 50 to 100 feet; and whether there will also be hail associated with the wind.

Workshop participants noted that natural infrastructure is extremely important. They discussed how to bring ecosystem well-being into the operation and building of hard infrastructure. For example, in the past, a nuclear power plant nearly shut down because a lack of water was impacting nearby wetlands. Impacts on natural systems are not generally considered; instead, economics drives a focus on hard infrastructure. For good design, participants noted, we need 
to know both what human needs are and what nature's needs are. They asked how to quantify interactions between ecostructure and infrastructure, and what the local-scale impact of and to green infrastructure would be. To answer these questions will require much more granular information on local conditions (especially soils) than currently exists.

\subsection{SCENARIO PLANNING}

Groups role-played as city and energy managers to discover specific information needs. They focused on three different climate change scenarios, in turn, each from the perspective of city administration, and from the perspective of a utility provider. The three scenarios were rising temperatures/drought, extreme precipitation, and extreme storms/wind.

For each scenario, discussion groups answered the following questions:

- In what ways could this change affect you?

- What types of action could be taken with existing practices, processes, and systems to guard against or prepare more fully for these impacts?

- What types of actions could be taken to guard against or better prepare for these impacts but requiring new institutional systems/processes/practices (either brand new or borrowed from other sectors/industries)?

\section{Rising Temperatures/Drought}

First, groups discussed how city administration and utility providers would react to rising temperatures and/or drought (Figure 2). Table F-4 in Appendix F summarizes the takeaways from these discussions, and findings are discussed in greater detail below.

Rising temperatures and drought could affect city administration in several ways. For example, action could include additional green infrastructure to decrease heat islands, and therefore more jobs to support it. Roads and rails could melt and crack due to the heat, and the movement of people could be affected by this road and rail

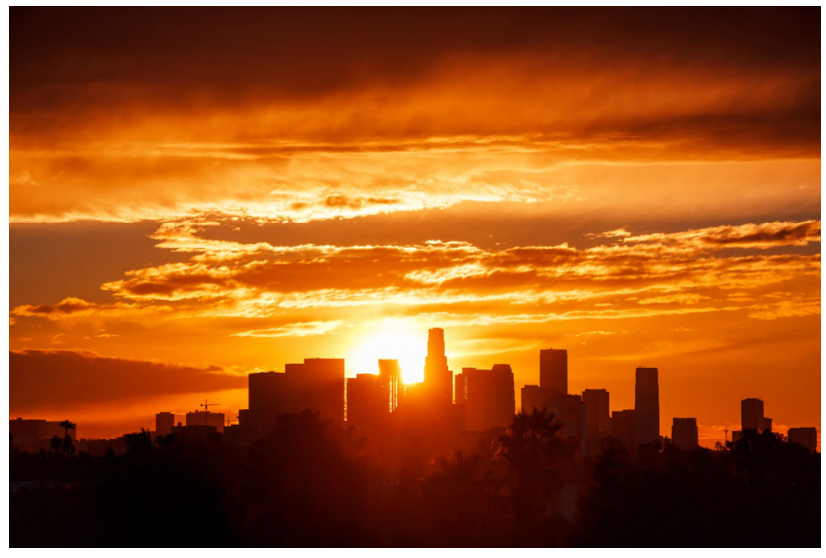

FIGURE 2 Cities Must Learn to Adapt to Higher Temperatures. damage. There may be less need for snow removal, but a greater need for insect control. The costs of water treatment could increase. Rising ozone and particulate matter would result in more people going to emergency rooms with respiratory ailments.

Workshop participants suggested several actions that cities could take with existing practices, processes, and systems to guard against and prepare more fully for the impacts of rising temperatures and drought. These include better two-way communications: from cities, of services and resources for vulnerable populations, and from vulnerable communities, of their needs and interests. Developing resources such as cooling centers and transportation, emergency services, messaging through community networks, and the provision of residential 
air-conditioning and a resilient, decentralized grid could all be priority actions in economically needy areas.

Some additional practical strategies could include preparing for blackouts to build redundancy and increase the deployment of batteries. Cities could address residents opening fire hydrants for cooling by providing more public fountains. They could air-condition all schools. More resources could be allocated to road and rail repair. Increases in home energy-use efficiency could take advantage of federal home assistance. Energy-use efficiency could be increased through demand response pricing, green roofs, and staggered office hours with incentives to modify hours of operations/services personnel to off-peak hours. Mapping out heat islands across the city could allow mitigation with green infrastructure. Improved and increased use of green infrastructure could include integration with the community, expanding current programs, strategically targeting for social and physical impacts, and providing high school internships on green energy. Participants noted that more research on green infrastructure's effectiveness and cost is needed to support its use.

Cities could also take several actions that require new systems, processes, or practices. Systems similar to 3-1-1 phone lines could be used to monitor infrastructure. Urban planning could be designed to maximize air temperature benefits. Modeling could help integrate technology better. Parks could be planned for heat resilience. New materials could be explored and used to construct roads and hard surfaces (with a concurrent need to adjust related codes to reflect these advances). Energy building codes could also be adjusted. Technology that could help includes nuclear reactors at mini or local levels to provide power, microgrids, solar shingles, smart solar power (tracking sun), building-scale (rooftop) wind energy, using biomimicry to design buildings better, and smart city monitoring that uses new sensors, solar power with battery monitors, and internet connections.

Rising temperatures and drought could affect utility providers in several ways. In conditions of rising temperatures and drought, workshop participants expected demand for utility services to increase. Temporal variability in demand would also go up. Reliability would decrease because it is difficult to adjust fossil fuel, nuclear power, and renewables to rapidly changing demand. Water reductions would also affect nuclear cooling and reduce the efficiency of nuclear power plants. Participants expect costs to go up, which may upset customers: insurance costs will go up, and environmental violations and associated fines may also go up, and those costs will be passed along. Operational safety could be more challenging; for example, utility workers who need to conduct maintenance or make repairs outdoors will be affected by the increased heat.

Workshop participants suggested several actions that utility providers could take with existing practices, processes, and systems to guard against and prepare more fully for the impacts of rising temperatures and drought. They could prepare and educate the public by communicating urgency for people to adapt, getting support from public stakeholders, tying messaging to climatic events, and encouraging cultural change. They could promote demand-response contracts, in which customers would voluntarily curtail the use of nonessential operations. They could lobby for building efficiency policies, and support regulatory standards to reduce nonessential energy consumption during periods of high demand. Utilities could develop cooperative agreements with each other. Utility providers could incentivize use of energyefficient technologies and to incentivize time of use based on weather forecasts. They could use existing data to identify at-risk systems and apply software tools to benchmark energy use at facilities. To minimize safety concerns for operational staff, they could reduce shift times, increase the utility workforce, and improve training. 
Utility providers could also take several actions that require new systems, processes, or practices. They could provide carbon reduction incentives for customers to promote reducing demand, develop more effective messaging around energy use and conservation, create utility/private partnerships to share resources (cooperative agreements), and develop and promote building energy efficiency. They could promote distributed energy resources in residential areas and through the use of brownfields for solar panels. Climate data-based integrated forecast models could be tied to grid operations. Workshop participants would like to use automated metering to improve the efficiency of power distribution in real time (15-minute intervals). Smart systems could integrate weather and/or climate data to forecast or mitigate demand challenges, and modeling tools could be developed to evaluate at-risk transmission equipment; the rotational load shedding approach could circumvent at-risk transmission lines and reroute power to areas that are at risk.

In addition, workshop participants suggested applying data mining and evaluation to identify efficiencies, optimization, and risks. They would like to develop advanced energy storage technologies (e.g., batteries) and use carbon sequestration to enable use of traditional fossil generation systems as baseload. Building redundancy into the grid would improve grid resilience and reduce worker exposure to temperature extremes. Developing non-heatproducing ways of cooling buildings (e.g., desiccant cooling) could involve finding ways to store or share excess heat between buildings and make better use of waste heat. Safety could be improved by promoting more automated equipment to reduce human exposure, but it is important to be wary of cyber risks in doing so.

\section{Extreme Precipitation}

Next, groups discussed how city administration and utility providers would react to rising extreme precipitation (Figure 3). Table F-5 in Appendix F summarizes the takeaways from these discussions, and findings are discussed in greater detail below.

Extreme precipitation could affect city administration in several ways. Flooding may have different impacts on different socioeconomic groups; it is important for city administrators to understand them. Extreme precipitation may reduce the city's attractiveness for tourism, new businesses, and new residents. There could be an overall decrease in property values and increase in insurance. Health impacts would occur as a result of the inundation of living spaces (e.g., basements, sewer backups) and as overflow at wastewater treatment plants creates associated water-quality impacts. Potentially, inundation could also create ideal conditions for mosquito breeding and the spread of mosquito-borne disease. Emergency plans would need to be altered to allow response people and vehicles in inundated areas to reach those in need. Cities would encounter damaged roads, buildings, and other infrastructure (including water and gas pipes). When utilities are down, safety risks would increase, and more buildings could flood as pumps may not work. There could be multiple impacts on transportation, including traffic impacts and accidents, as well as local and global air 
transport impacts, as the region is an international hub. Winter impacts include increased snow removal costs, as well as increased salt applications and associated contamination.

Workshop participants suggested several actions that cities could take with existing practices, processes, and systems to guard against and prepare more fully for the impacts of extreme precipitation. They could enhance employees' ability to telecommute, and strategically prioritize needed interventions. County and city ordinances regulating permeable surfaces could be used to mitigate flooding. Cities need to develop evacuation plans based on hazards and risks, adapt and train emergency responders for flood conditions, strengthen quick turnaround for repairs, and increase mosquito control spraying. More dams could possibly increase water retention while also providing opportunities for recreation. Cities should harden electrical infrastructure to protect it from floods. They could also promote methods to retain water upstream in soils, such as bioswales, wetlands, permeable paving, rain barrels, and green roofs, and they could incentivize solar and battery backup power for sump pumps.

Cities could also take several actions that require new systems, processes, or practices. They could encourage sweeping public education on environmental and climate topics. Changing utility regulations could allow them to adapt business practices to promote resilience. They could encourage flexibility in the insurance business to incentivize good behaviors, and develop revolving loan funds for impacted small businesses. Water pricing could change during times of heavy precipitation. Floodplains should be redefined. Airports should be diversified, decentralized, and reconfigured to handle extreme weather. Developing and promoting water reuse technology would allow cities to treat and reuse excess water. Roadways could be redesigned to eliminate underpasses where water collects and avoid areas that are prone to flooding. Cities could replace road pavement with permeable concrete and promote vertical parking spaces, convert vacant lots to water holding area and plant more trees (Houston and Detroit are excellent models), and reduce impermeable acreage by reducing parking minimums for new buildings. Increasing urban ecosystems could address mosquito problems by using birds and bats.

Extreme precipitation could affect utility providers in several ways. Flooding would impede workers dispatched to make repairs. Employees would be unable to get to work due to flooding. Electric generation could suffer if excess water makes it harder to get cooling water to power plants. Assets could be damaged by flooding.

Workshop participants suggested several actions that utility providers could take with existing practices, processes, and systems to guard against and prepare more fully for the impacts of extreme precipitation. They could recommend that the public not use water for nonessential household purposes during an extreme precipitation event to minimize sewer volumes. Ensuring that commercial and housing developments are responsible for managing the first small amount of rain in an event could decrease the stress on the system. Providers could build, maintain, and site assets using existing 50- and 100-yr floodplain data if those were updated to climate change risks. They could track and trend rainfall, and use weather forecasts for planning. Workshop participants suggested adding new water features to public spaces and architecture. If utilities can buy high-risk houses and buildings that flood often, they could then be converted to different uses. It is important to increase and maintain existing wetlands, and to plant trees to absorb water more quickly.

Utility providers could also take several actions that require new systems, processes, or practices. They could develop and execute a campaign to let the public know that "all water is recycled already" in a nod to natural systems (One Water Concept) to facilitate more flexible 
water use and treatment. Ordinances could be implemented that require all new construction to reduce precipitation runoff. More water could be retained upstream if utilities or cities promote retention tools such as rain barrels to divert system load, require $60-90 \%$ of stormwater to be treated onsite, and promote water redistribution to other areas that are experiencing shortages. Making gray water reuse mandatory would reduce load on the water treatment system. Building smart water operating systems could improve operations during a storm. Artificial intelligence and machine learning could improve the efficiency of water use in real time. Using drones to check for flooded streets could be an efficient substitute for workers inspecting roads. To improve planning and response, workshop participants would like to see the development of very fine-resolution (100-m grid) urban-scale weather forecasting.

\section{Extreme Storms/Wind}

Finally, groups discussed how city administration and utility providers would react to extreme storms and/or wind (Figure 4). Table F-6 in Appendix F summarizes the takeaways from these discussions, and findings are discussed in greater detail below.

Extreme storms and wind could affect city administration in several ways. Within green spaces, high winds can cause dangerous conditions (e.g., tree and branch fall) for the public. Extreme storms and wind will negatively impact public transit, rail lines, healthcare and hospitals, the intermodal

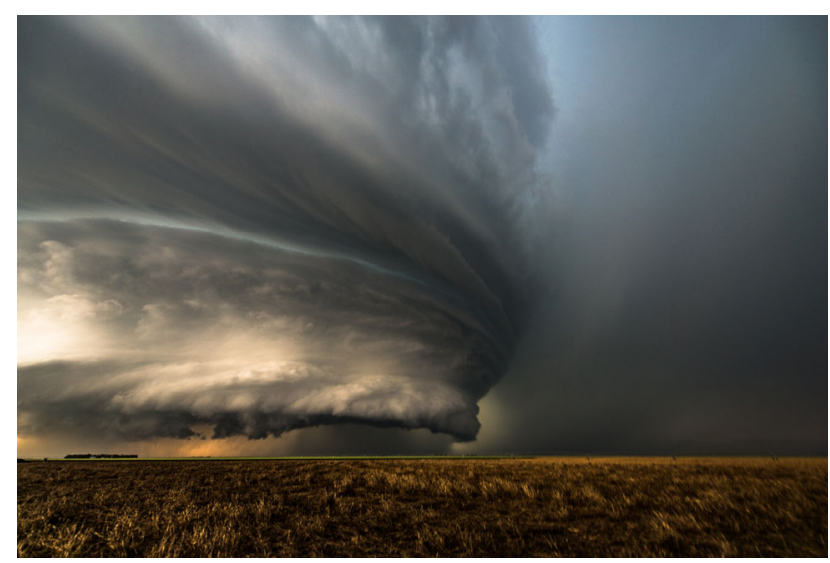

FIGURE 4 Extreme Storms Pose Risks to Infrastructure and Crops.

flow of goods, and supply chains. Ice events create power distribution impacts, damage buildings, and intensify salting efforts. Fluctuating temperatures cause building and asphalt damage (more potholes) and increase the need to dedicate resources to road management.

Workshop participants suggested several actions that cities could take with existing practices, processes, and systems to guard against and prepare more fully for the impacts of extreme storms and wind. They could create new design standards so when they repair roads, buildings, and other infrastructure, they proactively ensure that this infrastructure is better prepared for the next disaster. Cities could act as coordinating bodies between local entities. Cities could partner with counties and companies to pool resources and address gaps. It would be helpful to find ways to streamline and empower people with temporary emergency waivers. Cities could also coordinate exercises to prepare for extreme events and, like Florida, offer temporary shutters to protect windows. They could evaluate and strengthen existing structures to protect against higher wind loads, and build backups.

Cities could also take several actions that require new systems, processes, or practices. Workshop participants suggested building local resilience into planning (microgrids, zoning, etc.), sharing metering infrastructure, and distributing resources from larger jurisdictions to smaller communities. Cities could partner with utilities to tap into each other's resources for monitoring weather events and improve real-time data on storm precipitation with denser measurements. 
Extreme storms and wind could affect utility providers in several ways. Currently, utilities are forced to get regulatory approval to become more responsive and more resilient. Ice on powerlines and roads can impact safety of response and slow operation response to power outages; in addition, revenues from customers may decrease if they experience outages or simply do not receive power. If extremes cycle rapidly, infrastructure may be subject to greater stress. However, as extreme events occur, their individual impacts on infrastructure may decline (e.g., the second event could be much worse than the eighth event) if utilities become accustomed to them and mount a more organized response. Impacts can be organized around physical infrastructure and its interdependencies. There will be a greater need to track vulnerable customers. Latent infrastructure problems will appear. Operations will require forecasts to be more accurate and will depend more on these forecasts. Utilities believe they must be able to manage customers usage. Possible business model impacts could occur as more customers begin to exercise autonomy (e.g., home generation with solar power). It is necessary to recognize that solar and wind energy generation may be impacted-not just transmission. Response operations will require greater regional dependency and accounting.

Workshop participants suggested several actions that utility providers could take to improve existing practices, processes, and systems to guard against and prepare more fully for the impacts of extreme storms and wind. Critical customers are already building redundancies. Utilities could review prior failures for patterns to aid in triage management. They could also prioritize community response and support over individual customer response and support.

Utility providers could also take several actions that require new systems, processes, or practices. It is important to improve public understanding, but doing so will require several things to happen: utilities need a data source that can be trusted by communities; they need transparency on how they compute probabilities and resources to interpret that (i.e., people who can explain and have credibility); they need to increase scientific literacy influence; they need to build trust and community through communications (and learn through social media mistakes and wins); they need to influence human decision-making by communicating uncertainty and risk to the public (stir people to action, change behavior, invest in technology); and they need to use better, more convincing visualizations in technical and risk communication. Utilities need economic validation of resilience investment, and supporting models that are able to quantify economic impact. They need to develop better metrics and standardize institutional regulations to drive and advocate for resilience and modeling. State legislature can drive resilient utility development (bottom-up or top-down could work in this). Utilities should recognize that more disasters can mean more resilience. They need a system to standardize infrastructure repairs that drive net improved resilience ("FEMA paradox"-resilience through disaster). Workshop participants wanted to develop the ability to forecast how bad "near-term" seasons will be, and they wanted more local-scale forecasts. They suggested building more systems that share resources (e.g., heating and/or cooling balances in buildings) and diminishing dependency on single energy sources.

\subsection{CURRENT INFORMATION NEEDS AND DATA}

The participants were asked to review the information needs that had been identified earlier during the scenario discussion and to sort them into four buckets along a continuum of availability: (1) we have the information, (2) we have the capacity to obtain the information, (3) we are developing methods to be able to get the information, and (4) we need new research to understand how to get the information. The participants responses appear in Appendix $F$, Table F-7. 
Of particular interest to all the participants was the identification of information needs necessitating new research directions. This information requires new methodologies or new understanding; data are not available, and we do not yet have the understanding or methodology to acquire the needed information. Most of the identified needs in this bucket loosely cluster into needs that require new understanding of human behavior, new understanding of climate and weather, or new understanding or design of infrastructure.

The human factor in risk analysis and resiliency presented several new research directions. Participants wanted a better understanding of how emotions impact decisions and improved ability to predict both emotional and economic impacts of changes. They wanted tools that would allow them to effectively raise awareness at the neighborhood scale and that encompass the full spectrum of stakeholders, including nonprofits, planning agencies, and neighborhood organizations. They wanted to be able to predict how climate change would cause people to alter their behaviors with respect to what they do inside versus outside. Finally, they wanted soft infrastructure (e.g., training, institutions) to support effective decision-making and allow them to quantify tradeoffs.

Multiple climate and weather-related needs requiring new research were identified. Participants wanted precipitation data at much finer temporal and spatial scales (hourly, 100-m scales) and the ability to model flash floods at those scales-and even finer scales (10-minute frequency was preferred for flooding). They wanted to understand cloud cover duration, both now and in the future, at the scale of a small county so they could better predict solar energy. Information on ice storms and hail was of significant interest. Participants wanted future climate models to be able to predict hail frequency. They wanted the ability to predict snow and ice accumulation (of particular note, ice accumulation on poles and lines) and snow drifts as a function of wind and temperatures and precipitation. They wanted 30- and 90-day forecasts of extreme events, and to understand the probability of joint extreme events occurring in the future (e.g., an ice storm followed by a tornado).

Infrastructure needs that require new research are broad and multifaceted. All participants recognized that infrastructure assets interact with each other and will respond differently to climate changes. The ability to optimize the entire infrastructure system to maintain resilience is an overarching need, both now and in the face of changing climate, especially for city managers.

In addition, city managers wanted technology to make wastewater treatment effective even under extreme cold conditions. They also wanted the ability to do technoeconomic analyses of water systems based on regionally specific conditions and intelligent water and stormwater systems. They also identified a menu of green stormwater technologies along with characterization and associated performance as a need for urban decisionmakers, as well as expected changes in equipment schedules based on climate change. Energy providers wanted the ability to determine the net tradeoffs of preparing for an extreme event versus responding to an extreme event. Like city managers, they also wanted to understand how equipment requirements and schedules will need to evolve with climate change.

\subsection{MAJOR TAKEAWAYS}

At the end of the last day, participants discussed the major takeaways revealed during the course of the workshop. 
Participants agreed that climate models need to project not just current average temperatures, but also extreme high and low temperatures and data for specific situations (e.g., climate factors that affect livestock like cattle would differ from those that affect crops like grapes). There was consensus on the need to address and quantify the uncertainty in near-term (10-year) projections.

There was a desire for standardized model requirements to make climate models easier to compare. Participants also agreed that they need models with increasing levels of complexity and increased specificity (e.g., neighborhood-level data); they especially need fine-scale weather modeling in cities because spatial variability is greater there due to infrastructure (e.g., wind corridors).

There is also a need for flexible modeling frameworks that can account for large numbers of variables. Instead of capturing multi-dimensionality, participants suggested that we create a system that is user driven because there are too many design considerations to create separate models for everyone. The participants contended that there was a real need for more centralized access to data generated by climate models.

Two new modeling efforts were suggested as examples. The first was to develop a radial icing model that one could use to predict ice build-up based on weather conditions. The second was the suggestion to incorporate stormwater flows in hydrologic models coupled to climate models.

With regard to data considerations, the participants noted that data need to be localized and the community needs to be included in determining the data needs. Good data must be defensible, credible, and actionable. Data should also come from the user side (e.g., water utilities), not just the research side; participants suggested that Mesonet (http://mesonet.org/) a network of weather stations, which has been quite successful handling proprietary data, could provide examples of effective nondisclosure agreements. Mesonet is a statewide network of weather monitors across Oklahoma that provides real-time data to public and private customers.

Participants noted that modelers need to understand the mindset of and framework used by those generating different types of data, as well as how these data are obtained. Participants wanted to develop a data matrix for each sector so that they could compare multiple data types. The matrix must be multidimensional (i.e., consider multiple data and scales), it must be able to show causal relationships (how a affects $b$ ), and account for the complexities needed to address multiple stakeholders. If the matrix will inform standardization, perhaps it should be tailored to a broad audience to broaden usability.

Workshop participants said that communicators of risk and resiliency information must know their audience and communicate uncertainty in a way people can understand and use; they also need to understand what data decisionmakers need in order to make decisions, and how they make those decisions. Workshop participants noted that decisionmakers operate under complex regulatory constraints that must be taken into consideration when exploring action to reduce climate risk. Participants also recognized that decisionmakers struggle to differentiate between weather and climate and noted that it is important to understand when decisionmakers need weather information versus climate information. 


\section{NEXT STEPS}

The workshop made it clear that there is a need for a coordinated action to address resiliency to climate change. Workshop participants favored the creation of a consortium-like structure to address risk-related research pertaining to climate change; this structure would be composed of research institutions and public and private partners who are vested in a common goal of enabling a more resilient energy and environmental future. Through intentional collaboration with climate and decision support researchers, governmental and industrial participants felt they would be able to better meet their stakeholders' needs in the future. They argued that collaboration through this "consortium" would both enhance the credibility and relevance of the research results and improve the likelihood of creating accepted standards, analysis tools, and benchmark data.

Throughout the workshop, public and private managers voiced the need to ameliorate the current situation in which differing climate predictions are used for different sectors, and there is no gold standard. For example, one set of climate predictions may be used to assess flood risk, while another is used to assess grid vulnerability. Decisionmakers need trusted climate data and they do not have the ability to develop this resource themselves.

Industry and public managers participants to the workshop wanted to develop a collaboration with research institutions. They saw the need to join forces to defray and reduce costs, and improve quality and stakeholder acceptance.

The workshop participants envisioned the backbone of the collaboration would be the diverse expertise provided by participating institutions. Public and private partners would provide their deep understanding of infrastructure and operational needs, while climate and decision science researchers would provide scientific understanding, data, and tools useful for decision-making. Participants felt that the Argonne mission and experience in multidisciplinary, large-scale projects made it well suited to sheperding this collaboration. Argonne's capability to dynamically downscale global climate model predictions at unprecedented resolution and spatial extent could be a platform on which to integrate other distinct capabilities (for example, models addressing specific threat that are owned by other researchers), to enable science-based, local and/or regional, and complex decision-making that is vetted by consensus.

The workshop participants agreed that this collaboration could ensure data developed from downscaling science is effectively translated to drive both decision-support science and the development of analysis tools to tackle adaption to climate change impacts. A collaboration could also be better suited to address the risks to infrastructure and communities from extreme events to help build resiliency at the system-level and resolve multi-system dependencies. Currently, most industry climate resilience efforts evaluate infrastructure at the single asset scale and cannot consider risks of infrastructure interdependencies at the regional scale. The workshop made clear that communities and industry are struggling with how to evaluate multisystem dependencies.

Consensus is growing that the United States must address climate resilience. The envisioned collaboration offers a real opportunity to move forward in applying our best climate and decision support science now, in order to assure U.S. industry and public agencies can successfully adapt to and reduce the risks posed by climate change. 


\section{APPENDIX A: WORKSHOP AGENDA}

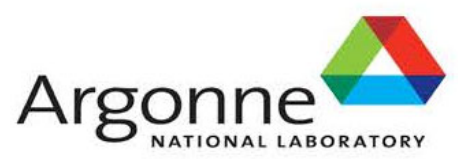

AGENDA

Assessing Climate Risks to Midwest Infrastructure Workshop Building 241-D172

July 25-26, 2019

Thursday, July $25^{\text {th }}$

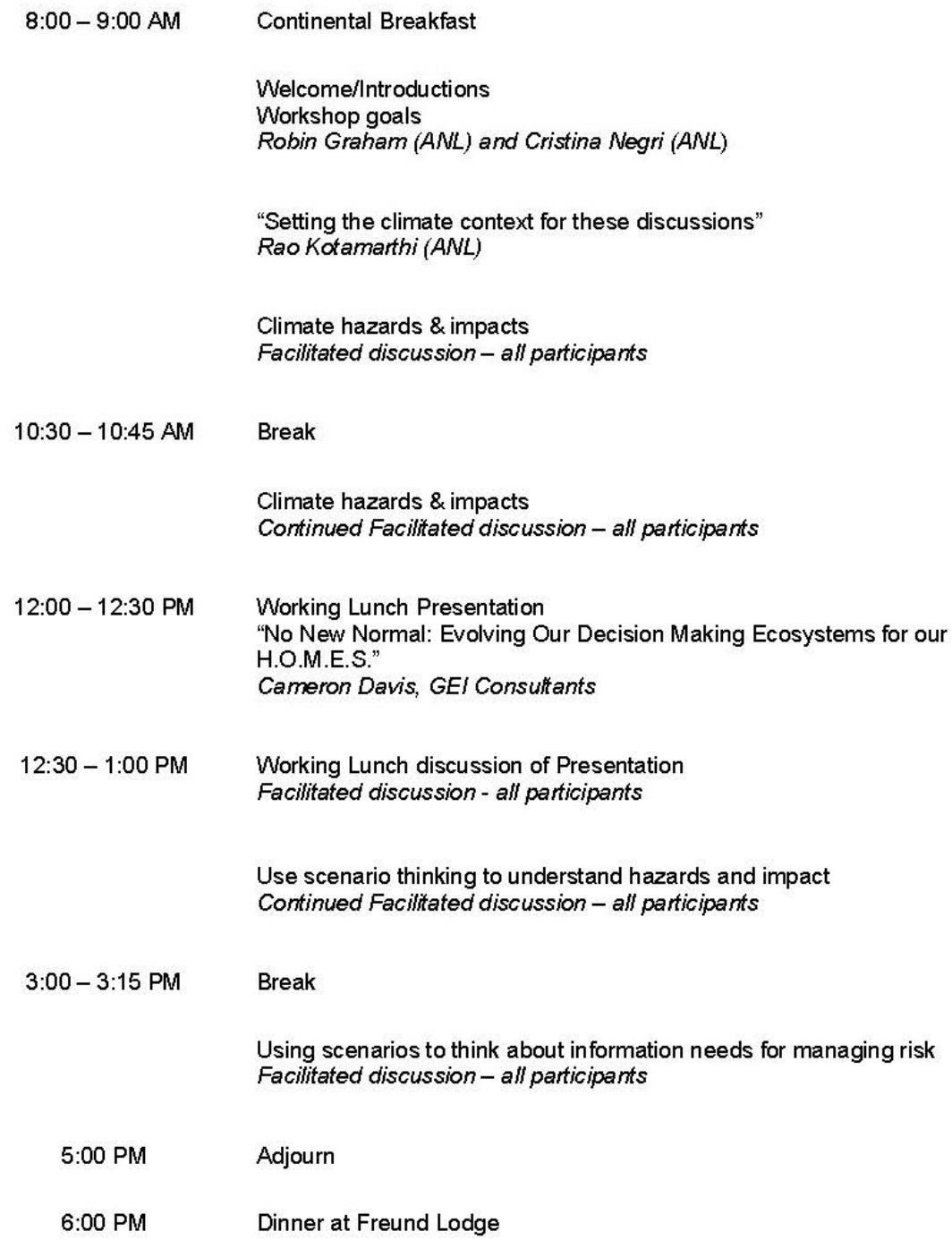




\section{Argonne}

Friday, July $26^{\text {th }}$

8:00-9:00 AM

Continental Breakfast

"The AT\&T experience assessing Climate Risk and business

planning"

Antoine Diffloth, AT\&T

From the business perspective of participants: Information needs for risk management

Facilitated discussion - all participants

10:30 - 10:45 AM Break

Continue facilitated discussion - all participants

12:00 - 1:00 PM Working Lunch: Next steps discussion

1:00-1:15 PM Break

1:15 - 5:00 PM Wrap-up meeting to discuss research implications and next steps based on the Workshop discussions - all are welcome; focus will be on research 


\section{APPENDIX B: LIST OF WORKSHOP PARTICIPANTS}

\begin{tabular}{|c|c|}
\hline Name & Affiliation \\
\hline Ellen Anderson & University of Minnesota \\
\hline Jim Angel & University of Illinois \\
\hline Julie Bessac & Argonne National Laboratory \\
\hline Justin Budd & Zurich Insurance \\
\hline Dan Chavas & Purdue University \\
\hline Brian Daly & Chicago Metropolitan Agency for Planning \\
\hline Cameron Davis & GEl Consultants \\
\hline Melanie Dickersbach & Exelon Corporation \\
\hline Yan Feng & Argonne National Laboratory \\
\hline Robin Graham & Argonne National Laboratory \\
\hline William Gutowski & lowa State University \\
\hline Rob Jacob & Argonne National Laboratory \\
\hline Rebecca Kartheiser & ComEd \\
\hline Rao Kotamarthi & Argonne National Laboratory \\
\hline David Kristovich & ISWS, Prairie Research Institute, University of Illinois in Urbana-Champaign \\
\hline Praveen Kumar & University of Illinois \\
\hline Kuldip Kumar & Metropolitan Water Reclamation District of Greater Chicago \\
\hline Mandy La Brier & City of Chicago \\
\hline Dina Lawrence & Commonwealth Edison, An Exelon Company \\
\hline Luke Leung & Skidmore, Owings, Merrill architectural firm (SOM) \\
\hline Mila Marshall & Delta Institute \\
\hline Katherine Moore Powell & The Field Museum \\
\hline Ralph Muehleisen & Argonne National Laboratory \\
\hline Cristina Negri & Argonne National Laboratory \\
\hline Aqdas Nida & Exelon \\
\hline Kevin O'Brien & Illinois Sustainable Technology Center / Illinois State Water Survey \\
\hline Mark Petri & Argonne National Laboratory \\
\hline Edward Podczerwinski & Metropolitan Water Reclamation District of Greater Chicago \\
\hline Akhilesh Ramakrishnan & Exelon \\
\hline Marzia Sedino & Skidmore, Owings, Merrill architectural firm (SOM) \\
\hline Rebecca Sheperd & Exelon ComEd \\
\hline Joe Svachula & Exelon Utilities \\
\hline Eugene Takle & lowa State University \\
\hline Dennis Todey & USDA-ARS \\
\hline Jean Utke & Allstate \\
\hline Thomas Wall & Argonne National Laboratory \\
\hline Jiali Wang & Argonne National Laboratory \\
\hline Eugene Yan & Argonne National Laboratory \\
\hline Mark Zoff & Exelon Corporation \\
\hline \multicolumn{2}{|l|}{ Workshop Support } \\
\hline Denise Fals & Argonne National Laboratory \\
\hline Sarah Fisk & Facilitator-Community At Work \\
\hline Mary Fitzpatrick & Argonne National Laboratory \\
\hline Sarah Lightfoot & Facilitator-Community At Work \\
\hline Alex Mitchell & Argonne National Laboratory \\
\hline Renee Plzak & Argonne National Laboratory \\
\hline Rudd Sadleir & Argonne National Laboratory \\
\hline Ben Schiltz & Argonne National Laboratory \\
\hline Carolyn Steele & Argonne National Laboratory \\
\hline
\end{tabular}




\section{APPENDIX C: RAO KOTAMARTHI WORKSHOP PRESENTATION}

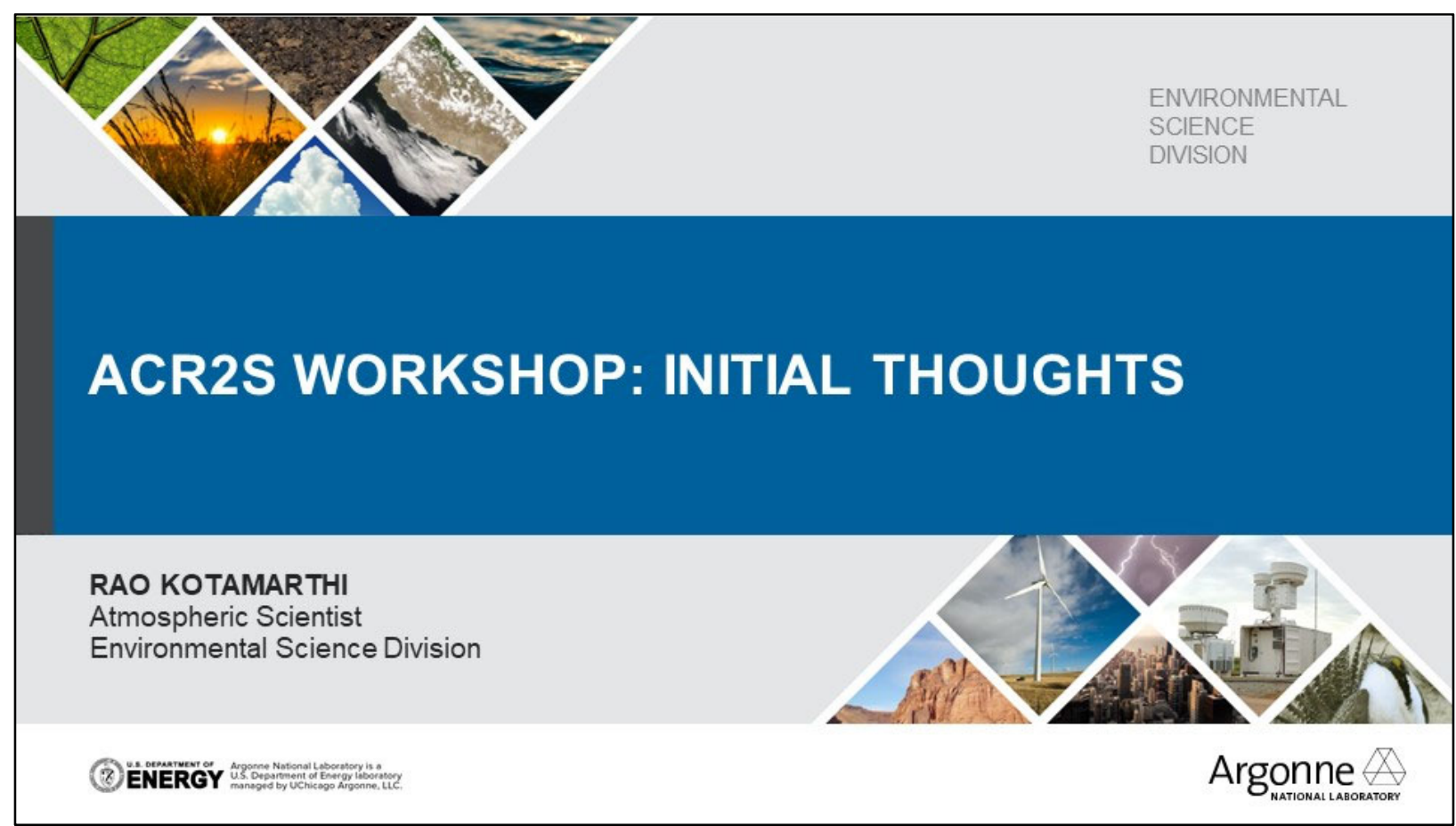

\section{REGIONAL CHANGES TEMPERATURE EXTREMES}

\#DAYS ABOVE HISTORICAL 95 PERCENTILE

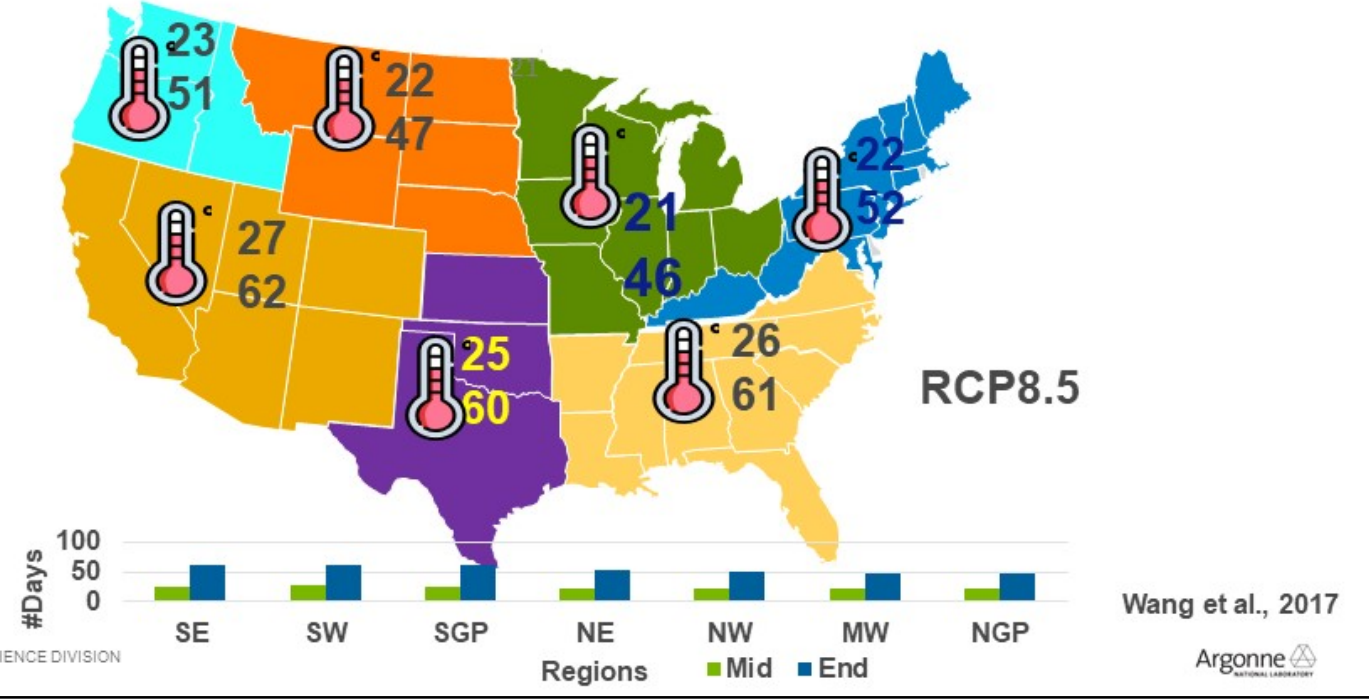




\section{REGIONAL CHANGES PRECIPITATION EXTREMES}

Moderate rainfall decreases, heavy rainfall increases

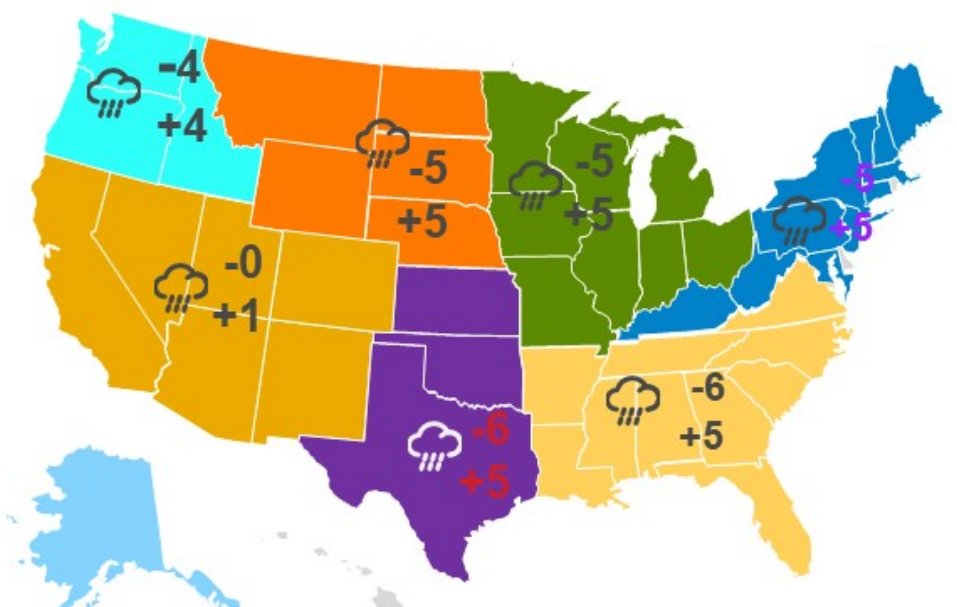

- is moderate rainfall $\left(0-60^{\text {th }}\right.$ percentile)

Weather and Climate Events
Physical, social, economic Coping/adaptive capacity

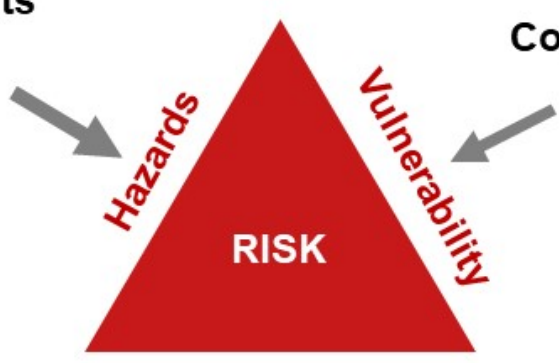

Exposure

4

Population, Infrastructure, Businesses 

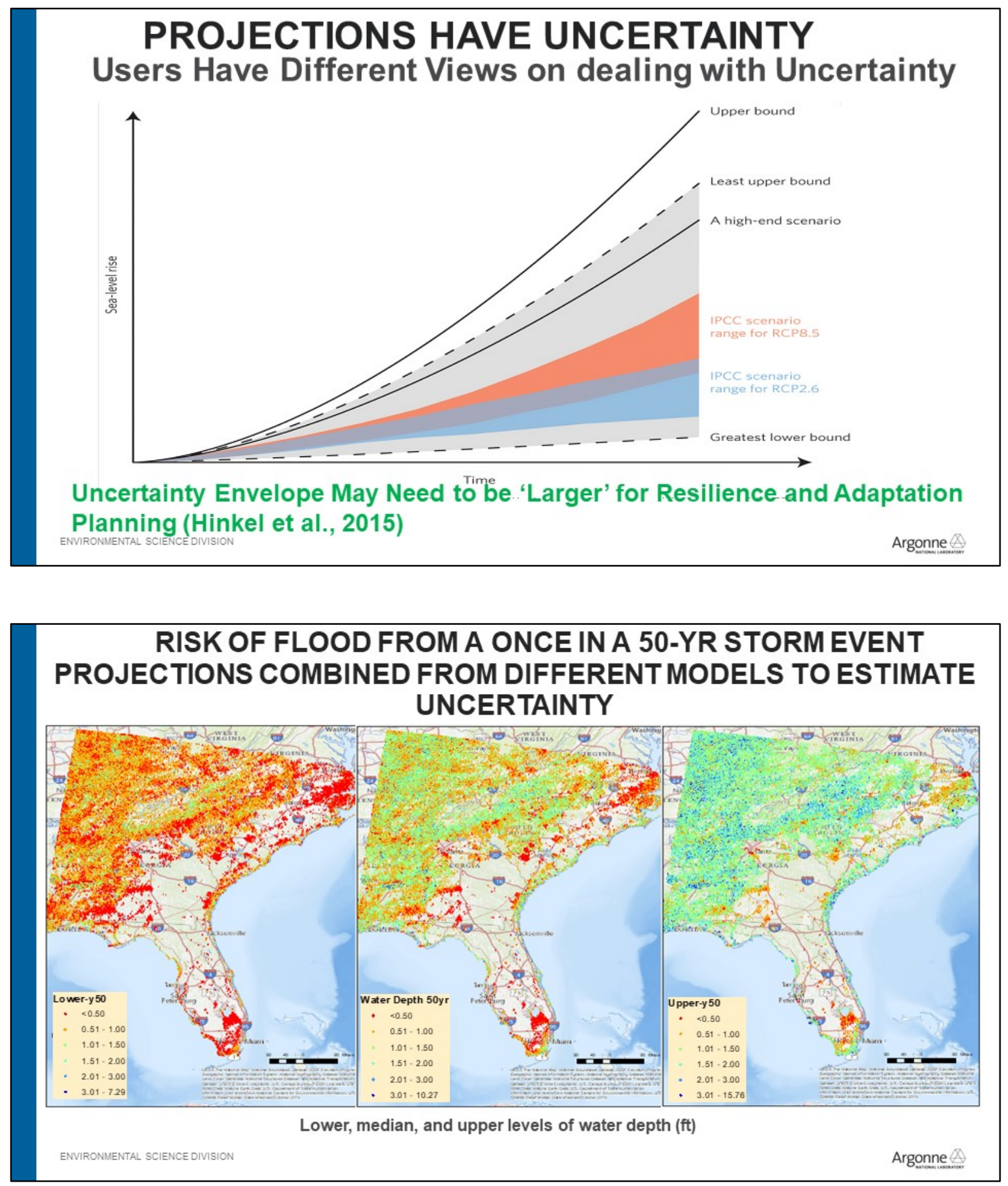


\section{HIGH RESOLUTION OUTPUT FOR ADAPTATION}

PLANNING Information is needed at the point of action

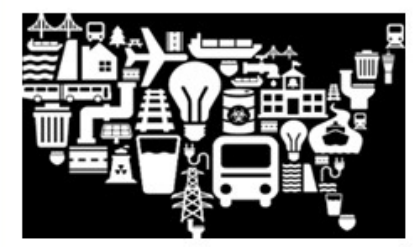

Infrastructure Scale
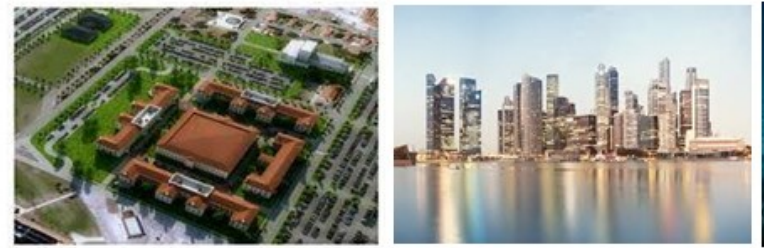

Installation Urban Scale Scale

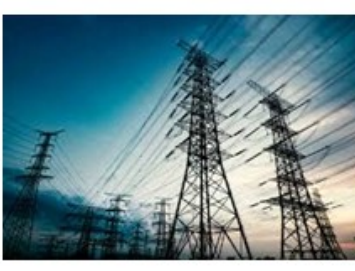

Operations Scale 
APPENDIX D: CAMERON DAVIS WORKSHOP PRESENTATION

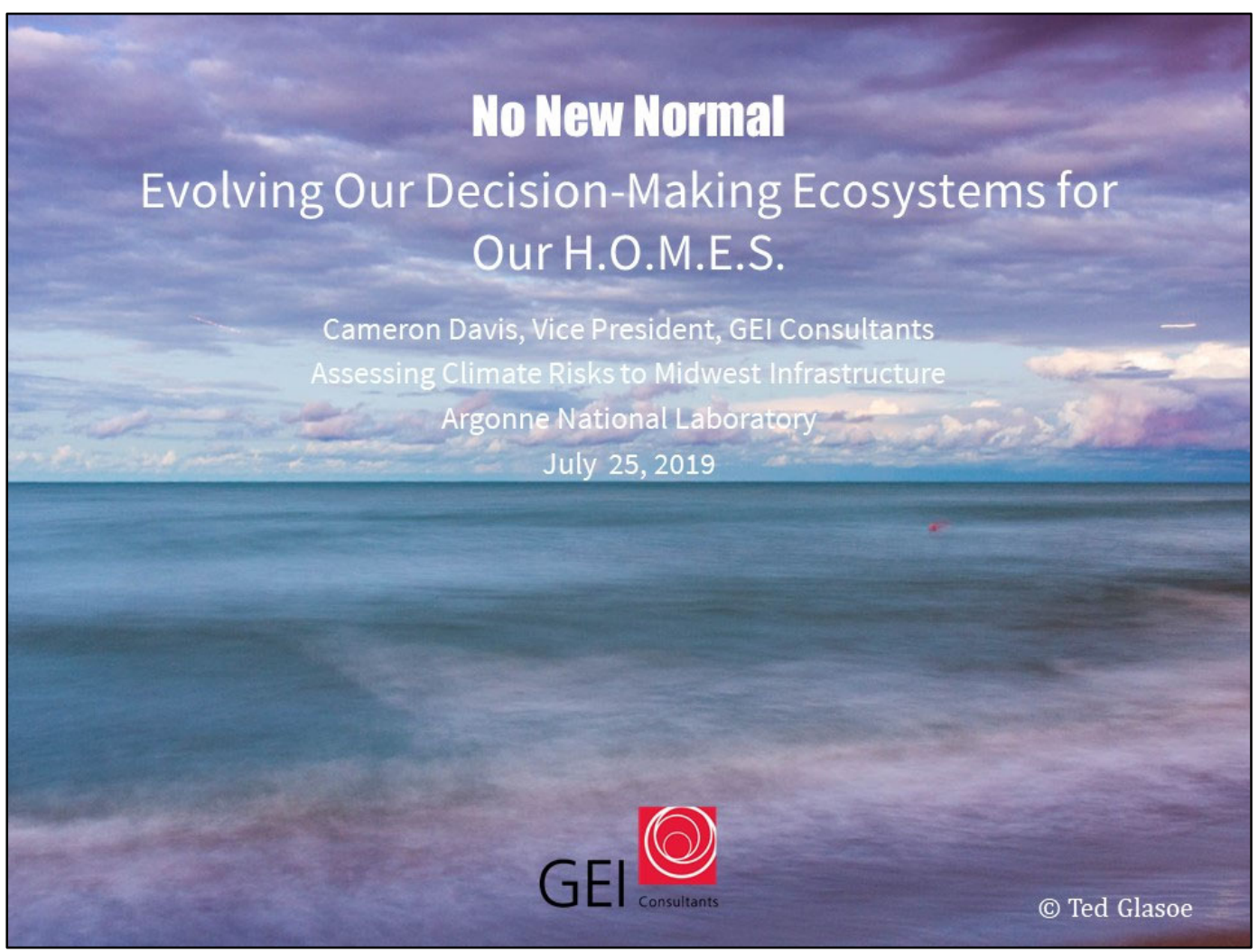




\section{Overview}

- Road-mapping resilience in decision-making

- Use the Great Lakes to tell the story

- Goal: provide another way to approach subsequent conversations during this conference 


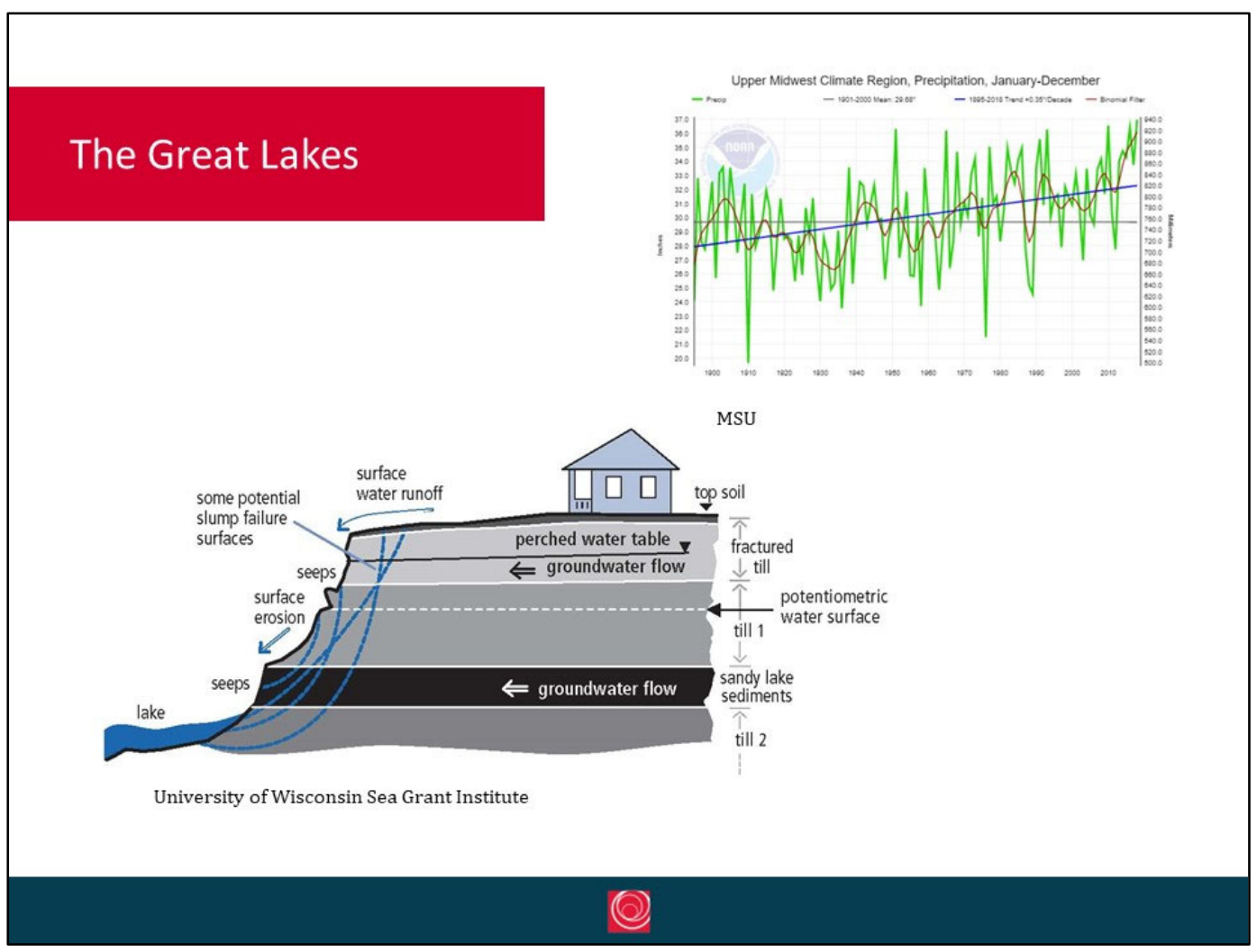




\section{Conclusions}

- Think of nature as a form of infrastructure that can help complement the resilience of built assets.

- We need to ensure our decision-making systems are as resilient and adaptable as our infrastructure and built assets.

- Resilient decision-making systems:

- Have a diversity of players

- Consider a diversity of data types

- Include action-forcing mechanisms into them so that results flow from data 


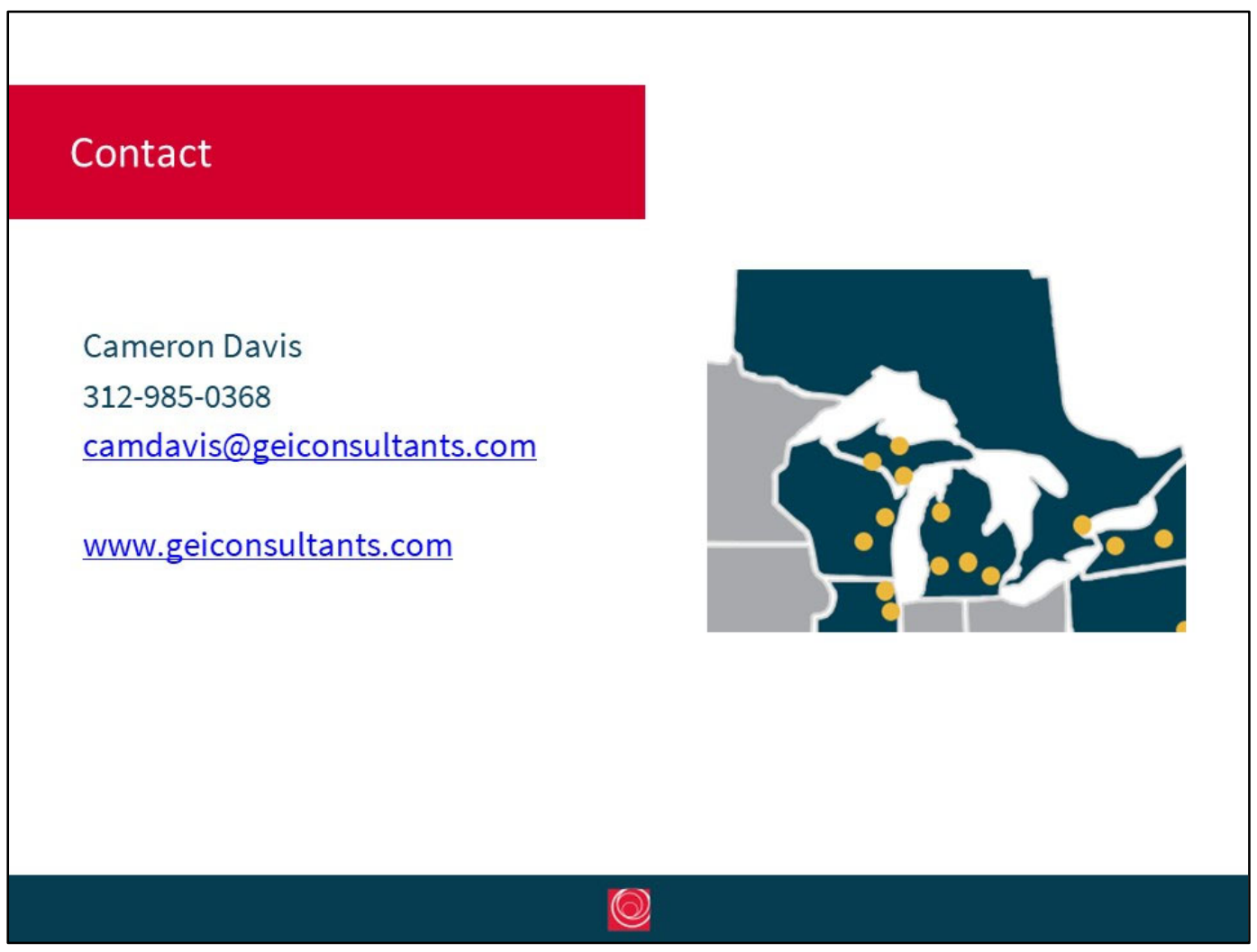


Climate Change Resiliency at AT\&T

Developing the AT\&T Climate Change Analysis Tool

The Process 


\section{Assessing the Need}

Before developing the tool AT\&T performed an assessment to see where we needed to strengthen our climate change resiliency position.

KEY FINDINGS OF RESILIENCY ASSESSMENT:

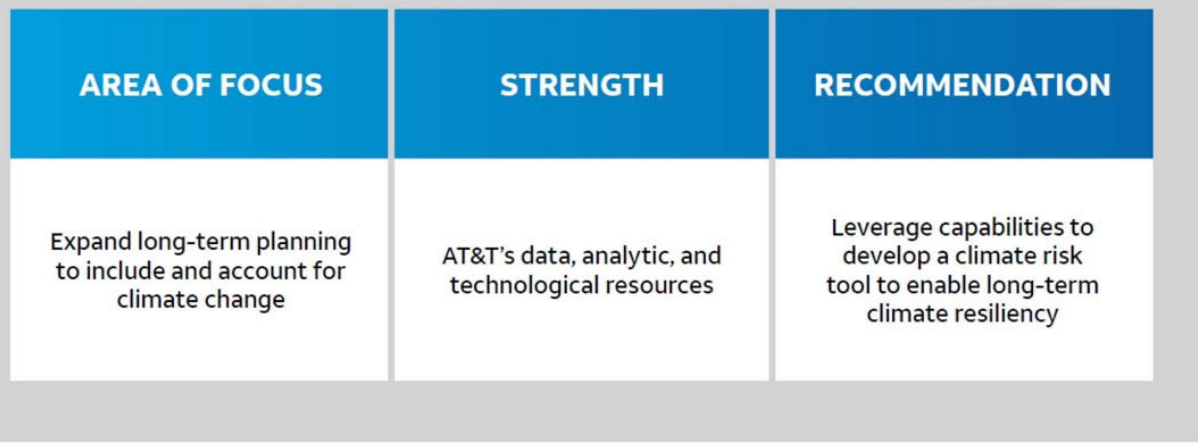

\section{The Scope}

It was important to

figure out the best

starting point. We

quickly realized that

we needed to begin

by picking a region

and relevant impact areas.

\section{SCOPE}

Understand the impact of climate change on ATRT's products and services and create a tool to visualize
climate change impacts on AT\&T assets by:

1. Better understanding the climate risk and resiliency challenges of a company with

2. Creating climate datasets to address the risk profiles relevant to AT\&T's business

3. Developing actionable high spatial resolution climate data products for use
in AT\&T's Climate Change Analysis Tool

4. Identifying research and data gaps for continued development of climate dat.
and science products to address identified risks and resiliency challenges

\section{PRIORITY STATES}

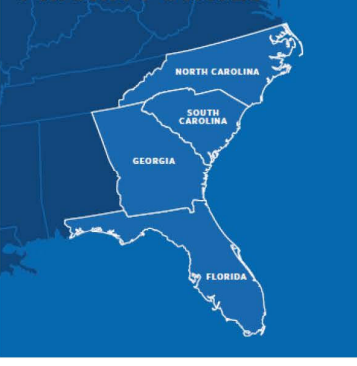

PRIORITY CLIMATE IMPACTS

Inland Flooding Caused y Increased Precipitation

Additional Coastal Flooding Caused by Sea Level Rise and Hurricane Surge

High-Intensity Winds (Non-Hurricane) 


\section{Identifying External Experts}

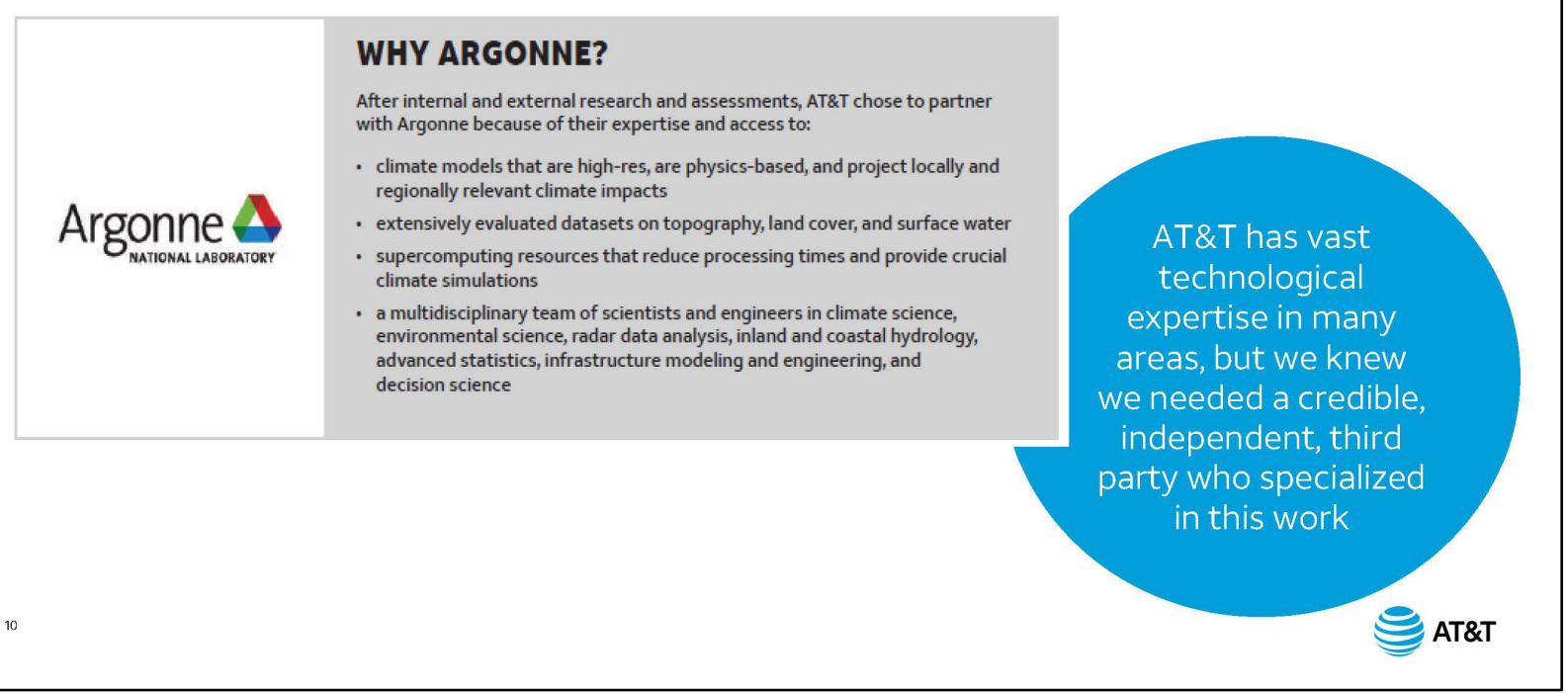

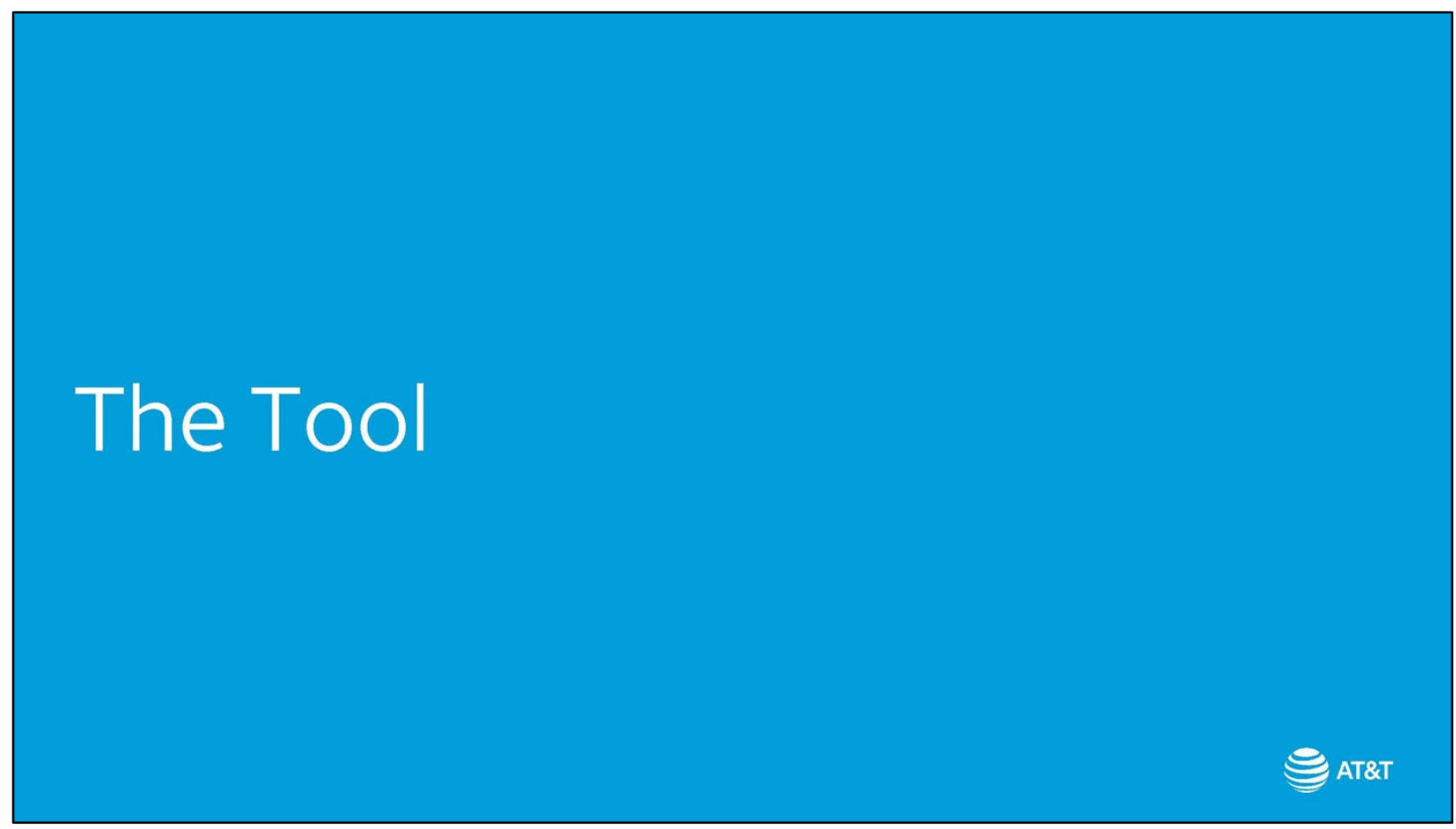




\section{AT\&T Climate Change Analysis Tool}

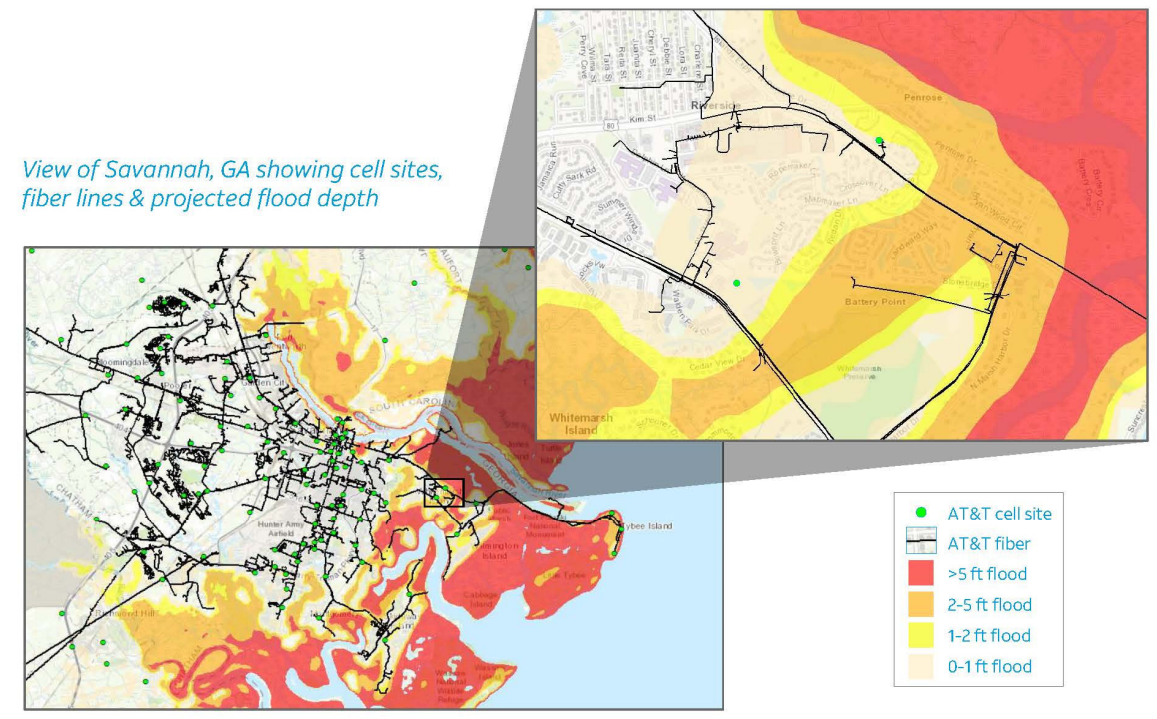

\section{AT\&T Climate Change Analysis Tool}

\section{Using the information generated by the CCAT}

- The CCAT will help anticipate potential impacts of climate change on our network infrastructure and business operations 30 years into the future.

- AT\&T plans to use the information generated by the tool to make data-driven decisions that will better serve our customers and improve our corporate resilience in the future.

- We anticipate that many AT\&T business units will leverage the data for a wide range of purposes. For example:

- Our networking planning and construction teams may use the data to plan where it will build out new infrastructure, such as cell sites, fiber and small cells to power our $5 \mathrm{G}$ network.

- Our corporate real estate team can use the data to site or plan for corporate offices, parking structures and other facilities.

- Our disaster recovery team can use the data to help anticipate where to place resources (such as generators and other equipment), so they are readily available in areas where climate-related impacts and events are likely to occur. 


\section{Publications and Media}

\section{White paper}

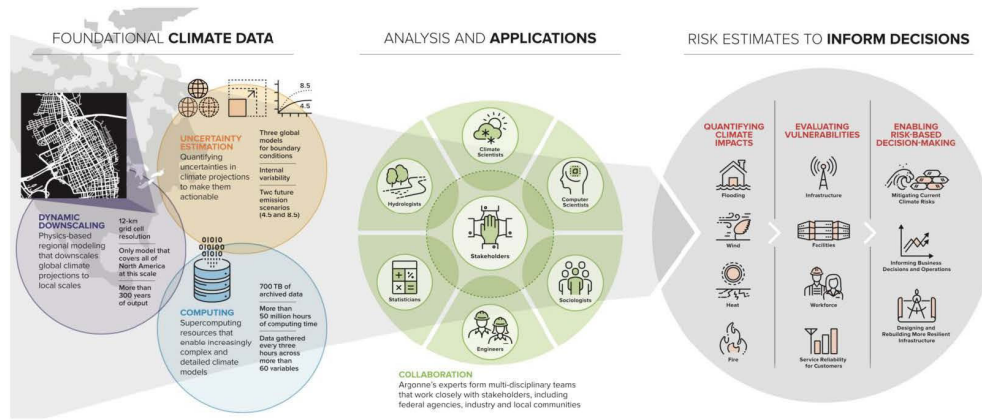

https://about.att.com/content/dam/csr/PDFs/RoadToClimateResiliency.pdf

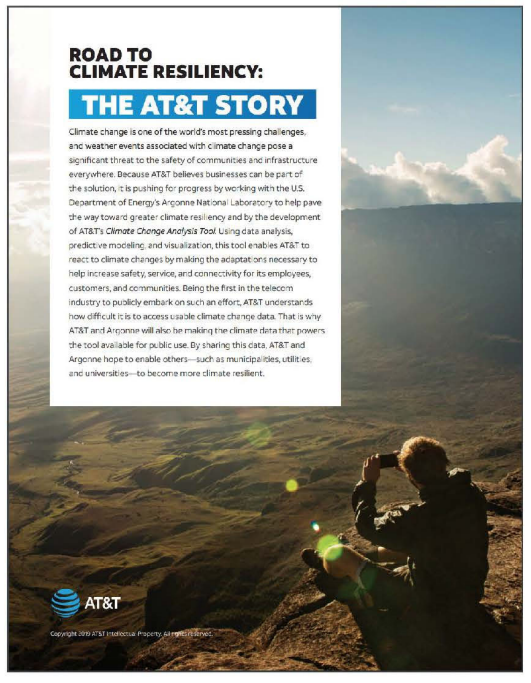




\section{Announcement}

\section{AT\&T press release}

AT\&T Engages U.S. Department of Energy's Argonne National

Laboratory on Industry-leading Climate Resiliency Project

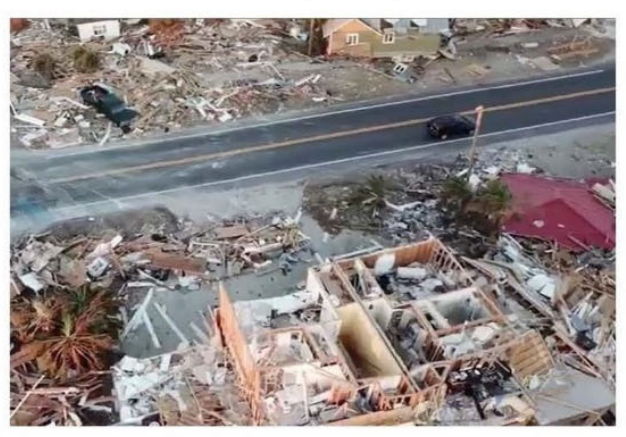

New Project will Help Assess Risks of Climate Change and Boost Climate Resiliency

\section{Argonne press release}

Argonne National Laboratory works with AT\&T on climate resiliency project

MARCH 27, 2019

Argonne's science keeps companies running and communities safe.

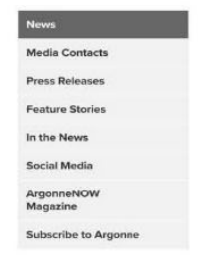

\section{Additional Climate Change Project Components}




\section{Community Climate Resiliency Challenge}

\section{Summary}

- Help local communities better predict and adapt to climate change impacts

- Universities partner with local municipalities to run a risk analysis

- AT\&T to provide funding for each team selected by a non-profit panel

- Each team will focus on one of four pilot states

\section{Social Objectives}

- Share data with local communities to assess the risk of climate change

- Extend CSR \& Philanthropy reach to next generation and student audience

- Increase climate change awareness \& the need for resiliency

\section{Business Climate Change Survey}

\section{Major Take-a-way}

AT\&T Survey Finds Most Companies View Climate Change as a Priority, but Have Not Yet Evaluated the Risks

\section{Summary}

- Commissioned by AT\&T

- Conducted by Morning Consult

- Almost $60 \%$ of companies view climate change as a priority

- Only $29 \%$ have assessed the risk of climate change to their business

- $38 \%$ have plan to respond to climate-related events 


\section{APPENDIX F: CONCERNS DISCUSSED DURING BRAINSTORMING SESSIONS}

TABLE F-1 Pressing Climate Concerns

\begin{tabular}{|c|c|}
\hline Category & Concerns \\
\hline Timeframe & $\begin{array}{l}\text { - Lack of political will } \\
\text { - Bridge political divide } \\
\text { - Public willingness to invest } \\
\text { - Ability to adapt to irreversible sea-level rise } \\
\text { - Translating data into action } \\
\text { - Focus of climate change regulations: competing priorities } \\
\text { - Intersecting trajectories (how climate, population growth, economics interact, } \\
\text { - feedbacks, and drivers) } \\
\text { - Climate change will become reality and models will prove right }\end{array}$ \\
\hline $\begin{array}{l}\text { Geopolitics and } \\
\text { Ecology }\end{array}$ & $\begin{array}{l}\text { - Climate migration and vulnerable populations } \\
\text { - Conflicts at global and/or regional scale } \\
\text { - Cultural and behavioral responses to climate change events will vary } \\
\text { - Ability to produce food } \\
\text { - Changing gross domestic product from agricultural production } \\
\text { - Balance adaptability with genotype persistence } \\
\text { - Biodiversity effects: green infrastructure may not adapt } \\
\text { - Secondary effects: disease insects, human migration } \\
\text { - Ecosystems with no place to go (estuaries) }\end{array}$ \\
\hline $\begin{array}{l}\text { Regional and } \\
\text { Community Impacts }\end{array}$ & $\begin{array}{l}\text { - Need for small communities to interact more broadly and globally } \\
\text { - Regional differences in climate change } \\
\text { - Regulate pollutants such as per- and polyfluoroalkyl substances (PFAS) in } \\
\text { - water and biosolids to ensure water availability } \\
\text { - Educating and empowering communities }\end{array}$ \\
\hline $\begin{array}{l}\text { Modeling and } \\
\text { Measuring Impacts }\end{array}$ & $\begin{array}{l}\text { - Increased precipitation } \\
\text { - Health concerns and air quality } \\
\text { - Impacts of severe weather events on daily life } \\
\text { - Higher demands and higher tax burdens } \\
\text { - Stormwater permits } \\
\text { - Soil loss and soil management } \\
\text { - Subtleties that climate models can reveal } \\
\text { - Changes in extreme weather events (simultaneous extremes) } \\
\text { - Modeling tools and skills are not keeping up with physical events } \\
\text { - Finding the right data to use for predictions }\end{array}$ \\
\hline
\end{tabular}


TABLE F-1 (Cont.)

\begin{tabular}{|c|c|}
\hline Category & Concerns \\
\hline Communication & $\begin{array}{l}\text { - Tone: convey urgency without causing despair or shutdown } \\
\text { - Need to dance around using the term "climate change" } \\
\text { - When does short-term climate information become available and useful? } \\
\text { - How to frame arguments to convince policymakers } \\
\text { - Need to better explain problems and implications } \\
\text { - Hard to communicate ranges and uncertainties to those responsible for } \\
\text { - planning and response } \\
\text { - } \text { Better communication of true issues to combat political points being made } \\
\text { - How to best communicate needed information on climate change to public } \\
\text { - Reconciling what climate science reports with what designers and engineers } \\
\quad \text { need }\end{array}$ \\
\hline $\begin{array}{l}\text { Infrastructure } \\
\text { Vulnerability }\end{array}$ & $\begin{array}{l}\text { - How do we adapt and increase resilience in the face of increasing } \\
\text { temperatures? } \\
\text { - System outages caused by extreme temperatures or weather events } \\
\text { - Cooling infrastructure: greater air conditioning needs increase pressure on } \\
\text { grid } \\
\text { - Proposed solutions are energy-intensive } \\
\text { - Can infrastructure handle peak energy loads? } \\
\text { - Exposure of infrastructure to extreme temperatures and/or weather events } \\
\text { - Understanding how electricity needs in communities will change } \\
\text { - Infrastructure not designed to handle extreme events }\end{array}$ \\
\hline $\begin{array}{l}\text { General or } \\
\text { Structural }\end{array}$ & $\begin{array}{l}\text { - Lack of consensus about how to direct investments to protect the future } \\
\text { - How to balance short-term versus long-term response to extreme events } \\
\text { - Competing funding priorities } \\
\text { - Need to better understand risks } \\
\text { - Reconciling different responses to risk calculations } \\
\text { - Business model concern: balancing stakeholder needs with limited } \\
\text { resources }\end{array}$ \\
\hline
\end{tabular}


TABLE F-2 Hazard Types and Impacts

\begin{tabular}{|c|c|}
\hline Hazard Type & Impact \\
\hline $\begin{array}{l}\text { Drought - } \\
\text { Increases in } \\
\text { Duration and/or } \\
\text { Frequency }\end{array}$ & $\begin{array}{l}\text { - Lack of water for households } \\
\text { - Lack of cooling water for power generation } \\
\text { - Lack of water for hydropower and industrial manufacturing } \\
\text { - Impact on domestic and wild animals } \\
\text { - Impact on food supply } \\
\text { - Impact on barge transportation } \\
\text { - Lack of preparation for water reuse } \\
\text { - Diminished water quality } \\
\text { - Vulnerability of perennial crops } \\
\text { - Lack of drought tolerant crops } \\
\text { - Pressure to increase irrigation use } \\
\text { - Aquifer drawdown } \\
\text { - Increased wind erosion vulnerability during droughts } \\
\text { - Inability of government agencies to coordinate responses } \\
\text { - Compounded events (e.g., wet followed by dry could increase wildfires) }\end{array}$ \\
\hline $\begin{array}{l}\text { Precipitation - } \\
\text { Increases in } \\
\text { Duration, } \\
\text { Frequency, or } \\
\text { Intensity, or } \\
\text { Changes in Form }\end{array}$ & $\begin{array}{l}\text { - Heavy snowstorms increase snow removal costs } \\
\text { - Heavy snowstorms can create supply chain problems for salt and fuel } \\
\text { - Heavy snowstorms decrease city revenue - limit tourism, conventions } \\
\text { - Heavy snowstorms increase roof repairs and repairs of other property } \\
\text { - Heavy snowstorms may necessitate changes in snow design life load for roofs } \\
\text { - Increase in number of freeze-thaw cycles decreases life cycle duration of } \\
\text { - Inaterials and infrastructure } \\
\text { - Intense rain storms overwhelm runoff infrastructure } \\
\text { - Increase rain storms lead to runoff pollution } \\
\text { - Increased humidity promotes airborne disease in built environments } \\
\text { - Increased humidity increases plant disease and human heat vulnerability } \\
\text { - Increased Ice storms impact power and transportation and infrastructure } \\
\text { - Increased hail causes increased damages to crops and infrastructure }\end{array}$ \\
\hline $\begin{array}{l}\text { Heat and } \\
\text { Heatwaves }\end{array}$ & $\begin{array}{l}\text { - Electric load increases due to air conditioning demand } \\
\text { - Ability of outdoor workers to respond goes down (intensity and duration of work } \\
\text { both go down) } \\
\text { - Ability for outdoor recreation can go down } \\
\text { - Create health impacts on vulnerable populations - very young, very old, those } \\
\text { with chronic illness, low income } \\
\text { - Increases electric loads that degrade power lines and transformers } \\
\text { - Increases loads that can lead to power outages or curtailments } \\
\text { - Creates thermal stress on infrastructure } \\
\text { O Roads buckle } \\
\text { O Planes grounded } \\
\text { - Rails affected } \\
\text { - Increases need for air conditioners in homes and places of work } \\
\text { - Overtaxes hospitals responding to human health impacts } \\
\text { - More frequent and/or intense heat waves may necessitate changes in building } \\
\text { - Nesign requirements } \\
\text { - Need to recognize what constitutes a heat wave or triggers a need to respond; } \\
\text { - Need to recognize local variation in neighborhood ability to mitigate heatwave }\end{array}$ \\
\hline
\end{tabular}


TABLE F-2 (Cont.)

\begin{tabular}{|c|c|}
\hline Hazard Type & Impact \\
\hline Flooding & $\begin{array}{l}\text { - Delays use of farm equipment (e.g., planting, harvesting) } \\
\text { - } \text { Damages/kills growing crops } \\
\text { - Increases water pollution } \\
\text { - Can impact drinking water supplies } \\
\text { - Can impact water treatment plants } \\
\text { - Can reduce emergency response time as vehicles avoid flooded areas } \\
\text { - Can cause public health issues (overflow of sewage) } \\
\text { - Basement flooding can increase fire hazards as fire pumps are often in } \\
\text { basements } \\
\text { - Regulations and industry standards need to be based on future conditions not } \\
\text { historic conditions } \\
\text { - Need to better understand how to consider energy infrastructure and } \\
\text { - } \text { Flooding in industrial areas can release toxic chemicals } \\
\text { - Increase in insurance losses and thus insurance rates }\end{array}$ \\
\hline $\begin{array}{l}\text { Wind and } \\
\text { Tornadoes }\end{array}$ & $\begin{array}{l}\text { - Increased winds impact air traffic, passengers } \\
\text { - If tornadoes frequency increase, building codes may need to change } \\
\text { - Increased wind loads increase building energy consumption } \\
\text { - Combination impacts (wind plus ice storm increases damage to trees and } \\
\text { infrastructure) } \\
\text { - Increased wind increases fire risks } \\
\text { - Wind damage frequently disrupts communication infrastructure impeding } \\
\text { emergency response } \\
\text { - Urban infrastructure impacts on extreme wind not well understood } \\
\text { - Lack of good information on hurricane and tornado projections of (1) intensity } \\
\text { and (2) frequency (hard to project future costs, or justify proactive investment) } \\
\text { - Poor historical data on tornados and severe weather } \\
\text { - Need future wind projection for wind energy } \\
\text { - Need future wind loads to develop building standards that provide resilience } \\
\text { - Wind variables needed to understand damage are } \\
\text { O Frequency, duration, and speed of wind gusts } \\
\text { O Wind direction } \\
\circ \text { Wind at height ( } 50 \text { to } 100 \mathrm{ft}) \\
\text { - If there is also hail }\end{array}$ \\
\hline Seasonality & $\begin{array}{l}\text { - Utilities have different risks in different seasons } \\
\text { - Changes in seasonality affect all farm operations } \\
\text { - Changes in seasonality impact insect abundance and animal behavior } \\
\text { - Changes in seasonality will affect municipal operations and equipment repair } \\
\text { - Peak load may change from summer to winter via electrification and decrease } \\
\text { usage of natural gas } \\
\text { - Currently a mismatch in Midwest between timing of electric energy demands } \\
\text { and wind power }\end{array}$ \\
\hline
\end{tabular}


TABLE F-2 (Cont.)

\begin{tabular}{|c|c|}
\hline Hazard Type & Impact \\
\hline Population Shifts & $\begin{array}{l}\text { - Midwest could experience population growth due to "climate refugees" from the } \\
\text { south or the coasts or fire-prone areas. } \\
\text { ○ Impact on taxes } \\
\text { ○ Impact on infrastructure needs } \\
\text { ○ Impact on municipal services } \\
\text { o Impact on regional politics/governance } \\
\text { - Current population growth projections (and concomitant planning) does not } \\
\text { include } \\
\circ \text { Climate refugees } \\
\text { - Lifestyle changes } \\
\text { - Changes in climate will effect industry location in unique and specific ways } \\
\text { (e.g., datacenters are not allowed by code to be in 100-year floodplains) }\end{array}$ \\
\hline $\begin{array}{l}\text { Crop Growing } \\
\text { Viability }\end{array}$ & $\begin{array}{l}\text { - Ability to do outdoor urban farming will decrease due to effect of heat on } \\
\text { - Iaborers } \\
\text { - Invasive species may be favored } \\
\text { - Pests and diseases will change due to rising temperature and humidity } \\
\text { - Lack of crop diversity in the Midwest increases risk } \\
\text { - Potential seasonal shift mismatches } \\
\text { - Mismatch between will change } \\
\text { Mroductive soils and beneficent climate }\end{array}$ \\
\hline Wildfire & $\begin{array}{l}\text { - Wildfire can destroy transmission line } \\
\text { - Smoke can contaminate equipment } \\
\text { - Smoke can decrease solar PV output } \\
\text { - Smoke can impact visibility and therefore transportation } \\
\text { - Wild fire risk may create intentional power outages } \\
\text { - Wild fire can be a deterrent to building alternative energy systems } \\
\text { - Insurance companies are challenged to price correctly given the dynamic } \\
\text { conditions } \\
\text { - Difficult to coordinate all agencies } \\
\text { - Risks to animals, plants and human life/health and mental health } \\
\text { o Poor air quality } \\
\text { O Damaged infrastructure of all types }\end{array}$ \\
\hline $\begin{array}{l}\text { Air and Water } \\
\text { Quality }\end{array}$ & $\begin{array}{l}\text { - Drought concentrates waste, creating smell and corrosion } \\
\text { - Storm water infrastructure not sufficient for current and future intense storms } \\
\text { - Ozone may increase with temperature } \\
\text { - Air contaminant chemistry may change with increased heat } \\
\text { - Need coupled air quality and climate models } \\
\text { - Shifts from fossil-based energy to solar or wind will generally improve air quality } \\
\text { O Reduce } \mathrm{NO}_{x} \text { emissions } \\
\text { o Reduce allergens }\end{array}$ \\
\hline Other & $\begin{array}{l}\text { - Great Lakes impact on meteorology not well-represented in ESM models } \\
\text { - Need for coordination across sectors to ensure efficiency and avoid } \\
\text { redundancies/islands of resilience } \\
\text { - Novel diseases may increase (Zika, West Nile, malaria vectors may increase) } \\
\text { - Need to consider regulatory driven consequences and meeting financial } \\
\text { constraints } \\
\text { - Need to consider centralized versus localized resilience (e.g., distributed energy } \\
\text { gives more resilience to weather extremes?) }\end{array}$ \\
\hline
\end{tabular}


TABLE F-2 (Cont.)

\begin{tabular}{|l|l|}
\hline \multicolumn{1}{|c|}{ Hazard Type } & \\
\hline Other (Cont.) & Impact \\
& Extreme Cold (e.g., polar vortex events) \\
& ○ Utility Crew response is impacted negatively \\
& $\circ$ Customers can suffer \\
& $\circ$ Negative effect on wind turbines \\
& $\circ$ Trees and other perennial vegetation negatively impacted \\
& ○ Income and customer differential impact underground equipment and \\
& saturated soils, causing ground expansion impact \\
\hline
\end{tabular}

TABLE F-3 Data Needs and Questions to Answer

\begin{tabular}{|l|l|}
\hline \multicolumn{1}{|c|}{ Category } & \\
\hline Social and & - If there is "no new normal" and we will be experiencing continuous change, \\
Political Questions & how do we plan for the future? \\
and the Decision- & - How do we quantify resilience? \\
making Process & - How does one measure success? \\
& $\begin{array}{l}\text { - How do we bring different stakeholders to the decision table? We lack this } \\
\text { ability and it affects our ability to discover scenarios where everyone wins }\end{array}$ \\
& $\begin{array}{l}\text { - At-risk groups (elderly, disabled, etc.) need to have a place at the decision } \\
\text { table (e.g., to avoid Chicago heat wave impacts) }\end{array}$ \\
& $\begin{array}{l}\text { Decisionmakers need a system to evaluate the potential impacts of } \\
\text { hypothesized actions }\end{array}$ \\
& $\begin{array}{l}\text { - Could we create an interactive resource to convene stakeholders? } \\
\text { - What is the resilience of process in decisions? }\end{array}$ \\
\hline - How do we motivate people to action? \\
- How do we convince decisionmakers to allocate funds to do integrated climate \\
research? Current funders are not integrated with one another.
\end{tabular}


TABLE F-3 (Cont.)

\begin{tabular}{|c|c|}
\hline Category & Data Needs \\
\hline $\begin{array}{l}\text { Standards Are } \\
\text { Important for } \\
\text { Decisionmakers }\end{array}$ & $\begin{array}{l}\text { - Can we create a methodology to update standards (infrastructure and other), } \\
\text { using climate projections? } \\
\text { - Likewise, a standard modeling approach could be beneficial for different } \\
\text { organizations to "talk climate" with each other and to rely on best practices in } \\
\text { a topic they are not familiar with } \\
\text { - Standardization of mandate/data/regulations/models would: } \\
\text { Build public support as it makes sense to Joe Public } \\
\text { Enable providing data in dashboard that average person could understand } \\
\text { Would help convey urgency of action - urgency is difficult to communicate } \\
\text { because of lack of standardization } \\
\text { Provide decisionmakers a common framework } \\
\text { Would help in understanding the business value proposition } \\
\text { - Help in portfolio management }\end{array}$ \\
\hline $\begin{array}{l}\text { Data Availability Is } \\
\text { Critical }\end{array}$ & $\begin{array}{l}\text { - Climate data and projections need to be accessible to those who forecast } \\
\text { energy loads for buildings } \\
\text { - Digitization of climate data would enable: } \\
\text { o Facility operations to address trends and capital investments } \\
\text { - More sophisticated data and business models } \\
\text { - We need user friendly climate change models available to all } \\
\text { - We need understand and provide information on model biases } \\
\text { - Building energy usage data is not accessible; this hampers understanding how } \\
\text { climate affects energy usage and how building design modifies that usage } \\
\text { - Suggestion - create an open source data portal on public building energy } \\
\text { usage so researchers and engineers can better understand/predict climate } \\
\text { impacts of building energy use }\end{array}$ \\
\hline $\begin{array}{l}\text { Recognizing } \\
\text { Significance of } \\
\text { Natural Features }\end{array}$ & $\begin{array}{l}\text { - How do we bring ecosystem well-being into operating and building hard } \\
\text { infrastructure? For example, nuclear plant nearly shut down due to lack of } \\
\text { water for wetlands } \\
\text { - Impact on natural systems not considered; focus on infrastructure driven by } \\
\text { economic reasons } \\
\text { - For good design we need to know both what human needs are but also } \\
\text { nature's needs } \\
\text { - How do we quantify interactions between ecostructure and infrastructure? } \\
\text { - What is the local-scale impact of green infrastructure? } \\
\text { - We need more detailed maps of soils characteristics; current public maps are } \\
\text { insufficient }\end{array}$ \\
\hline $\begin{array}{l}\text { Miscellaneous } \\
\text { Concerns }\end{array}$ & $\begin{array}{l}\text { - Are climate trends in just one direction? Or do they fluctuate/change direction } \\
\text { repeatedly? } \\
\text { - Governments and industry sectors need to both let suppliers know what their } \\
\text { contract needs will be in the future to meet targets for the future and poll } \\
\text { suppliers as to whether they can meet those goals? }\end{array}$ \\
\hline
\end{tabular}


TABLE F-4 Effects of Rising Temperatures/Drought

\begin{tabular}{|c|c|c|}
\hline Question & City Administration & Utility Provider \\
\hline $\begin{array}{l}\text { In what ways could this } \\
\text { change affect you? }\end{array}$ & $\begin{array}{l}\text { - Additional green infrastructure } \\
\text { - More renewable jobs associated } \\
\text { with green infrastructure } \\
\text { - Roads and rails melt and crack } \\
\text { - Movement of people affected by } \\
\text { road and rail damage } \\
\text { - Less snow removal } \\
\text { - Greater need for insect control } \\
\text { - Increased costs of water } \\
\text { treatment } \\
\text { - Rising ozone and } \mathrm{PM}_{2.5} \text { result in } \\
\text { more people in emergency rooms }\end{array}$ & $\begin{array}{l}\text { - Demand will go up } \\
\text { - Temporal variability in demand will } \\
\text { go up } \\
\text { - Reliability will go down because: } \\
\text { o Fossil, nuclear, renewables do } \\
\text { not easily adjust to rapidly } \\
\text { changing demand } \\
\text { - Water reductions will affect } \\
\text { nuclear cooling and reduce } \\
\text { efficiency of plant } \\
\text { - Costs will go up and anger } \\
\text { customers } \\
\text { - Insurance costs will go up } \\
\text { - Environmental violation and fines } \\
\text { may go up } \\
\text { - Operational safety could be more } \\
\text { challenging }\end{array}$ \\
\hline $\begin{array}{l}\text { What types of action } \\
\text { could be taken with } \\
\text { existing practices, } \\
\text { processes, and systems } \\
\text { to guard against or } \\
\text { prepare more fully for } \\
\text { these impacts? }\end{array}$ & $\begin{array}{l}\text { - Better communication of services, } \\
\text { resources for vulnerable } \\
\text { populations } \\
\text { - Cooling centers and } \\
\text { transportation to centers } \\
\text { - Emergency services } \\
\text { - Messaging through community } \\
\text { networks } \\
\text { - Provide resident air-conditioning } \\
\text { - Focus actions on economically } \\
\text { needy areas with community } \\
\text { input } \\
\text { o Give voice to those who are } \\
\text { needy } \\
\text { - Focus on vulnerable first } \\
\text { - Prepare for blackouts } \\
\text { ○ Build redundancy } \\
\text { ○ Support batteries } \\
\text { - Address fire hydrant opening with } \\
\text { fountains } \\
\text { - Air condition ALL schools } \\
\text { - Target more resources to road } \\
\text { and rail repair } \\
\text { - Increase energy use efficiency } \\
\text { o Federal home assistance } \\
\text { ○ Demand response pricing } \\
\text { ○ Green roofs } \\
\text { - Staggered office hours } \\
\text { - Map heat islands across the city } \\
\text { and mitigate with green } \\
\text { infrastructure }\end{array}$ & $\begin{array}{l}\text { - Prepare/educate the public } \\
\text { - Communicate urgency for people } \\
\text { to adapt } \\
\text { - Get support from public } \\
\text { stakeholders } \\
\text { - Tie messaging to climatic events } \\
\text { - Encourage cultural change } \\
\text { - Promote demand response } \\
\text { contracts (customers curtail use of } \\
\text { nonessential operations) } \\
\text { - Lobby for building efficiency } \\
\text { policies } \\
\text { - Support regulatory standards to } \\
\text { reduce nonessential energy } \\
\text { consumption during periods of } \\
\text { high demand } \\
\text { - Develop cooperative agreements } \\
\text { between utilities } \\
\text { - Incentivize energy-efficient } \\
\text { technology } \\
\text { o Incentivize time of use } \\
\text { o Tie to climate forecast } \\
\text { - Use data to identify at-risk systems } \\
\text { - Apply software tools to benchmark } \\
\text { energy use at facilities } \\
\text { - Combat safety concerns for } \\
\text { operational staff } \\
\text { o Reduce shift times } \\
\text { o Increase utility workforce } \\
\text { O Improve training }\end{array}$ \\
\hline
\end{tabular}


TABLE F-4 (Cont.)

\begin{tabular}{|c|c|c|}
\hline Question & City Administration & Utility Provider \\
\hline $\begin{array}{l}\text { What types of action } \\
\text { could be taken with } \\
\text { existing practices, } \\
\text { processes, and systems } \\
\text { to guard against or } \\
\text { prepare more fully for } \\
\text { these impacts? (Cont.) }\end{array}$ & $\begin{array}{l}\text { - Better/more green infrastructure } \\
\text { - Research effectiveness, expense, } \\
\text { Operations and maintenance } \\
\text { - Integrate with community } \\
\text { - Expand current programs } \\
\text { - Target strategically for social and } \\
\text { physical impact } \\
\text { - Provide high school internships } \\
\text { on green energy }\end{array}$ & \\
\hline $\begin{array}{l}\text { What types of actions } \\
\text { could be taken to guard } \\
\text { against or better prepare } \\
\text { for these impacts but } \\
\text { require new institutional } \\
\text { systems, processes, or } \\
\text { practices? }\end{array}$ & $\begin{array}{l}\text { - Systems (e.g., 3-1-1) to monitor } \\
\text { infrastructure } \\
\text { - Urban planning design to } \\
\text { maximize air temperature } \\
\text { benefits } \\
\text { - Better integrated modeling of } \\
\text { technology } \\
\text { - Plan for heat-resilient parks } \\
\text { - Explore new materials for roads } \\
\text { and hard surfaces and adjust } \\
\text { codes } \\
\text { - Standardize energy building } \\
\text { codes } \\
\text { - Technology that could help } \\
\text { - Nuclear reactors at mini or local } \\
\text { level to provide power } \\
\text { - Microgrids } \\
\text { - Solar shingles } \\
\text { - Smart solar (tracking sun) } \\
\text { - Building-scale (rooftop) wind } \\
\text { - Using biomimicry to better design } \\
\text { buildings } \\
\text { - Smart city monitoring } \\
\text { - New sensors } \\
\text { - Solar power with battery monitors } \\
\text { - Tied to internet }\end{array}$ & $\begin{array}{l}\text { - Provide carbon reduction } \\
\text { incentives for customers } \\
\text { - Develop more effective messaging } \\
\text { around energy use/conservation } \\
\text { - Create utility/private partnerships } \\
\text { to share resources } \\
\text { - Develop/promote building energy } \\
\text { efficiency } \\
\text { - Promote distributed energy } \\
\text { resources } \\
\text { o Residential } \\
\text { o Use brownfields for solar panels } \\
\text { - Climate data-based integrated } \\
\text { forecast model tied to grid } \\
\text { operations } \\
\text { - Analyze in real time } \\
\text { - Automate metering to improve } \\
\text { efficiency of power distribution } \\
\text { o Develop smart systems that } \\
\text { integrate weather/climate data to } \\
\text { forecast/mitigate demand } \\
\text { challenges } \\
\text { o Develop models to evaluate at- } \\
\text { risk transmission equipment } \\
\text { - Use rolling method to circumvent } \\
\text { at risk transmission lines and to } \\
\text { reroute power to areas at risk } \\
\text { - Apply data mining/evaluation to } \\
\text { identify } \\
\text { efficiencies/optimization/risks } \\
\text { - Develop advanced storage } \\
\text { technologies } \\
\text { - Use carbon sequestration to } \\
\text { enable use of traditional fossil } \\
\text { generation systems as baseload } \\
\text { - Build redundancy into the grid to } \\
\text { o Improve grid resilience } \\
\text { o Reduce worker exposure to } \\
\text { temperature extremes }\end{array}$ \\
\hline
\end{tabular}


TABLE F-4 (Cont.)

\begin{tabular}{|c|c|c|}
\hline Question & City Administration & Utility Provider \\
\hline $\begin{array}{l}\text { What types of actions } \\
\text { could be taken to guard } \\
\text { against or better prepare } \\
\text { for these impacts but } \\
\text { require new institutional } \\
\text { systems, processes, or } \\
\text { practices? (Cont.) }\end{array}$ & & $\begin{array}{l}\text { - Develop non-heat-producing ways } \\
\text { to cool buildings } \\
\text { o Store/share excess heat } \\
\text { between buildings } \\
\text { o Make better use of waste heat } \\
\text { - Promote more automated } \\
\text { equipment to reduce human } \\
\text { exposure but be wary of cyber } \\
\text { risks in doing so }\end{array}$ \\
\hline
\end{tabular}

TABLE F-5 Effects of Extreme Precipitation

\begin{tabular}{|c|c|c|}
\hline Question & City Administration & Utility Provider \\
\hline $\begin{array}{l}\text { In what ways could this } \\
\text { change affect you? }\end{array}$ & 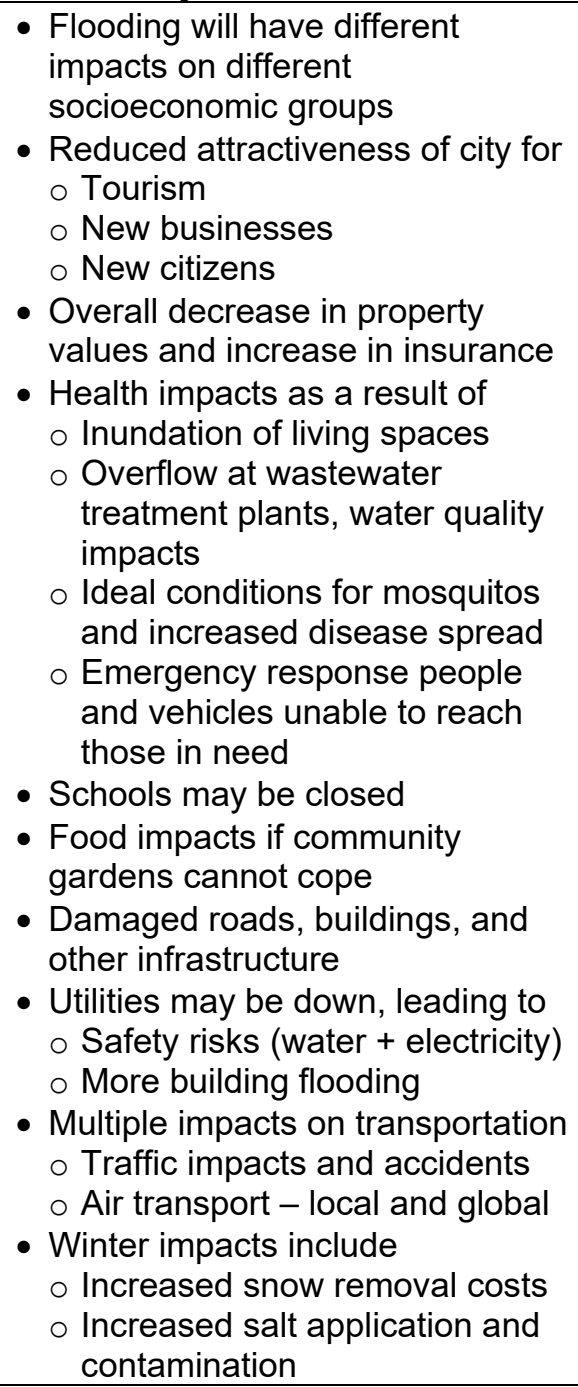 & $\begin{array}{l}\text { - Flooding would impede workers } \\
\text { dispatched to make repairs } \\
\text { - Employees unable to get to work } \\
\text { due to flooding } \\
\text { - Electric generation could suffer if } \\
\text { excess water makes it harder to get } \\
\text { cooling water to power plants } \\
\text { - Assets could be damaged by } \\
\text { flooding } \\
\text { - If power goes out, pumping stations } \\
\text { would not be able to move water, } \\
\text { which exacerbates flooding }\end{array}$ \\
\hline
\end{tabular}


TABLE F-5 (Cont.)

\begin{tabular}{|c|c|c|}
\hline Question & City Administration & Utility Provider \\
\hline $\begin{array}{l}\text { What types of action } \\
\text { could be taken with } \\
\text { existing practices, } \\
\text { processes, and systems } \\
\text { to guard against or } \\
\text { prepare more fully for } \\
\text { these impacts? }\end{array}$ & $\begin{array}{l}\text { - Enhance ability to telecommute } \\
\text { - Strategic prioritization of needed } \\
\text { interventions } \\
\text { - County and city ordinances on } \\
\text { permeable surfaces } \\
\text { - Develop evacuation plans based } \\
\text { on hazards and risks } \\
\text { - Adapt and train emergency } \\
\text { responders for flood conditions } \\
\text { - Quick turnaround for repairs } \\
\text { - Increase mosquito control } \\
\text { spraying } \\
\text { - More dams to increase water } \\
\text { retention and provide recreation } \\
\text { - Flood harden electrical } \\
\text { infrastructure } \\
\text { - Promote methods to retain water } \\
\text { upstream in soils } \\
\text { O Bioswales } \\
\text { o Wetlands } \\
\text { O Permeable paving } \\
\text { O Rain barrels } \\
\text { o Green roofs } \\
\text { - Incentivize solar and battery } \\
\text { backup power for sump pumps }\end{array}$ & $\begin{array}{l}\text { - Tell public to not use extra water for } \\
\text { household during an event } \\
\text { - Ensure developments are } \\
\text { responsible for managing first small } \\
\text { amount of rain } \\
\text { - Build/maintain/site assets using } \\
\text { existing 50- and 100-yr floodplain } \\
\text { data } \\
\text { - Track and trend rainfall, use } \\
\text { weather forecasts for planning } \\
\text { - Add new water features to public } \\
\text { spaces, architecture } \\
\text { - Buy high-risk houses/buildings that } \\
\text { flood often and convert to different } \\
\text { use } \\
\text { - Increase/maintain wetlands and } \\
\text { plant trees }\end{array}$ \\
\hline $\begin{array}{l}\text { What types of actions } \\
\text { could be taken to guard } \\
\text { against or better prepare } \\
\text { for these impacts but } \\
\text { require new institutional } \\
\text { systems, processes, or } \\
\text { practices? }\end{array}$ & $\begin{array}{l}\text { - Encourage broad public } \\
\text { education on environment and } \\
\text { climate topics } \\
\text { - Change utility regulations to allow } \\
\text { them to adapt business practices } \\
\text { to promote resilience } \\
\text { - Encourage flexibility in the } \\
\text { insurance business to incentivize } \\
\text { good behaviors } \\
\text { - Develop revolving loan funds for } \\
\text { impacted small businesses } \\
\text { - Effect water pricing difference in } \\
\text { times of heavy precipitation } \\
\text { - Redefine floodplains } \\
\text { - Diversify and decentralize } \\
\text { airports } \\
\text { - Reconfigure airports to handle } \\
\text { extreme weather } \\
\text { - Develop/promote technology to } \\
\text { treat/reuse excess water } \\
\text { - Redesign roadways } \\
\text { - Eliminate underpasses where } \\
\text { water collects } \\
\text { - Avoid areas that are prone to } \\
\text { flooding }\end{array}$ & $\begin{array}{l}\text { - Develop and execute a campaign to } \\
\text { let the public know all water is } \\
\text { recycled already to facilitate more } \\
\text { flexible water use and treatment } \\
\text { - Implement ordinance requiring all } \\
\text { new construction to reduce } \\
\text { precipitation runoff } \\
\text { - Retain more water upstream } \\
\text { o Promote rain barrel use to divert } \\
\text { system load } \\
\text { o } 60-90 \% \text { of stormwater treatment } \\
\text { onsite } \\
\text { o Promote water redistribution to } \\
\text { other areas with shortages } \\
\text { - Build smart water operating } \\
\text { systems to improves reaction } \\
\text { during a storm } \\
\text { - Use artificial intelligence/machine } \\
\text { learning to provide real-time water } \\
\text { use efficiency } \\
\text { - Use drones to check for flooded } \\
\text { streets so workers can avoid driving } \\
\text { on flooded roads } \\
\text { - Develop very fine resolution urban- } \\
\text { scale weather forecasting }\end{array}$ \\
\hline
\end{tabular}


TABLE F-5 (Cont.)

\begin{tabular}{|l|l|l|}
\hline \multicolumn{1}{|c|}{ Question } & \multicolumn{1}{c|}{ City Administration } & \multicolumn{1}{c|}{ Utility Provider } \\
\hline What types of actions & - Replace road pavement with & $\bullet$ Make gray water use mandatory to \\
could be taken to guard & permeable quiet concrete and \\
against or better prepare & promote vertical parking spaces \\
for these impacts but & - Convert vacant lots to water \\
require new institutional & holding area and plant more trees \\
systems, processes, or & - Reduce impermeable acreage by & \\
practices? (Cont.) & $\begin{array}{l}\text { reducing parking minimums for } \\
\text { new buildings }\end{array}$ & \\
& $\begin{array}{l}\text { Increase bat colonies to address } \\
\text { mosquitos }\end{array}$ & \\
& & \\
& & \\
\end{tabular}

TABLE F-6 Effects of Extreme Storms/Wind

\begin{tabular}{|c|c|c|}
\hline Question & City Administration & Utility Provider \\
\hline $\begin{array}{l}\text { In what ways could this } \\
\text { change affect you? }\end{array}$ & $\begin{array}{l}\text { - In green spaces, high winds can } \\
\text { cause dangerous conditions for } \\
\text { public } \\
\text { - Will negatively impact public } \\
\text { transit, rail lines, } \\
\text { healthcare/hospitals, flow of } \\
\text { goods, supply chains } \\
\text { - Ice events create power } \\
\text { distribution impacts, building } \\
\text { damage, and intensify salting } \\
\text { efforts } \\
\text { - Fluctuating temperatures cause } \\
\text { building and asphalt damage and } \\
\text { increase need to dedicate } \\
\text { resources to road management }\end{array}$ & $\begin{array}{l}\text { - Currently, utilities are forced to get } \\
\text { regulatory approval to become } \\
\text { responsive, more resilient } \\
\text { - Ice on powerlines and roads } \\
\text { o Can impact safety of response } \\
\text { o Can slow operation response to } \\
\text { power outages } \\
\text { o Customers may not pay bills if } \\
\text { they experience outages or simply } \\
\text { do not receive power } \\
\text { - Rapidly cycling extremes create } \\
\text { greater stress on infrastructure } \\
\text { - As many extreme events occur, } \\
\text { their individual infrastructure } \\
\text { impacts may decline } \\
\text { - Organize impacts around physical } \\
\text { infrastructure and dependency } \\
\text { infrastructure } \\
\text { - Greater need to track vulnerable } \\
\text { customers } \\
\text { - Latent infrastructure problems } \\
\text { appear } \\
\text { - Operations require more accurate } \\
\text { forecasts and depend more on } \\
\text { them } \\
\text { - Must manage customers' usage } \\
\text { - Possible business model impacts if } \\
\text { more customers exercise autonomy } \\
\text { - Solar and wind energy generation } \\
\text { may be impacted - not just } \\
\text { transmission } \\
\text { - Response operations require } \\
\text { greater regional dependency and } \\
\text { accounting }\end{array}$ \\
\hline
\end{tabular}


TABLE F-6 (Cont.)

\begin{tabular}{|c|c|c|}
\hline Question & City Administration & Utility Provider \\
\hline $\begin{array}{l}\text { What types of action could } \\
\text { be taken with existing } \\
\text { practices, processes, and } \\
\text { systems to guard against or } \\
\text { prepare more fully for these } \\
\text { impacts? }\end{array}$ & $\begin{array}{l}\text { - Create new design standard } \\
\text { so when you repair roads, } \\
\text { buildings, etc., they are better } \\
\text { prepared for the next disaster } \\
\text { - Have city act as coordinating } \\
\text { body between local entities } \\
\text { - City partners with county and } \\
\text { companies to pool resources } \\
\text { and address gaps } \\
\text { - Find ways to streamline and } \\
\text { empower people with } \\
\text { temporary emergency waivers } \\
\text { - Coordinate exercises to } \\
\text { prepare for extreme events } \\
\text { - Offer temporary shutters to } \\
\text { protect windows, etc. } \\
\text { - Evaluate/strengthen existing } \\
\text { structures to protect against } \\
\text { higher wind loads } \\
\text { - Build in backups }\end{array}$ & $\begin{array}{l}\text { - Critical customers are already } \\
\text { building redundancies } \\
\text { - Review prior failures for patterns to } \\
\text { triage management } \\
\text { - Promote community } \\
\text { response/support over individual } \\
\text { customer response/support }\end{array}$ \\
\hline $\begin{array}{l}\text { What types of actions could } \\
\text { be taken to guard against or } \\
\text { better prepare for these } \\
\text { impacts but requiring new } \\
\text { institutional systems/ } \\
\text { processes/practices? }\end{array}$ & $\begin{array}{l}\text { - Build local resilience into } \\
\text { planning } \\
\text { - Share metering infrastructure } \\
\text { - Distribute resources from } \\
\text { larger jurisdictions to smaller } \\
\text { communities } \\
\text { - Partner with utilities to monitor } \\
\text { weather events } \\
\text { - Improve real-time data on } \\
\text { storm precipitation with denser } \\
\text { measurements }\end{array}$ & $\begin{array}{l}\text { - Improve public understanding } \\
\text { ○ Need data sources to change } \\
\text { minds } \\
\text { ○ Need transparency on } \\
\text { probability computation and } \\
\text { resources } \\
\text { O Increase scientific } \\
\text { literacy/influence } \\
\text { ○ Build trust/community through } \\
\text { communications } \\
\text { - Partnerships/communication in } \\
\text { human decision-making } \\
\text { - Use better visualization in } \\
\text { communications } \\
\text { - Economic validation of resilience } \\
\text { investment } \\
\text { - Economic translation or reference } \\
\text { in model predictions } \\
\text { - Develop better metrics and } \\
\text { standardized institutional } \\
\text { regulations to drive/advocate } \\
\text { resilience and modeling } \\
\text { - State legislature can drive resilient } \\
\text { utility development } \\
\text { - More disasters mean more } \\
\text { resilience } \\
\text { - Standardize infrastructure repairs } \\
\text { that drive net improved resilience }\end{array}$ \\
\hline
\end{tabular}


TABLE F-6 (Cont.)

\begin{tabular}{|l|l|l|}
\hline \multicolumn{1}{|c|}{ Question } & \multicolumn{1}{|c|}{ City Administration } & \multicolumn{1}{c|}{ Utility Provider } \\
\hline $\begin{array}{l}\text { What types of actions could } \\
\text { be taken to guard against or } \\
\text { better prepare for these }\end{array}$ & & $\begin{array}{l}\text { - Develop ability to forecast how bad } \\
\text { "near term" seasons will be } \\
\text { impacts but requiring new } \\
\text { institutional systems/ } \\
\text { processes/practices? (Cont.) }\end{array}$ \\
& & $\begin{array}{l}\text { Need more local-scale forecasts } \\
\text { - Build systems that share } \\
\text { resources } \\
\text { - Diminish dependency on single } \\
\text { energy sources }\end{array}$ \\
\hline
\end{tabular}


TABLE F-7 Information Needs Identified by Workshop Participants

\begin{tabular}{|c|c|c|c|c|}
\hline $\begin{array}{l}\text { Type of } \\
\text { Change }\end{array}$ & Currently Available & $\begin{array}{l}\text { Information We Have the } \\
\text { Capacity to Obtain }\end{array}$ & $\begin{array}{l}\text { Information We Are Working on } \\
\text { with Methods under Development }\end{array}$ & $\begin{array}{c}\text { Information That Requires New } \\
\text { Research Directions }\end{array}$ \\
\hline $\begin{array}{l}\text { Rising } \\
\text { temperatures }\end{array}$ & $\begin{array}{l}\text { - Ways cities can adapt to } \\
\text { increasing temperatures } \\
\text { - How does humidity translate } \\
\text { to "total heat index?" } \\
\text { - } \quad \text { Influences load } \\
\quad \text { Influences worker } \\
\text { - Safety } \\
\text { temperature changes } \\
\text { - Clear comparison of } \\
\text { projected temperatures with } \\
\text { past actual temperatures- } \\
\text { needed for utility leadership } \\
\text { buy-in } \\
\text { - Temperatures, relative } \\
\text { humidity, and precipitation at } \\
\text { local scales, min-max } \\
\text { - Projections of heat events } \\
\text { (number of consecutive days } \\
\text { >90F) } \\
\text { - Climate/weather projections } \\
\text { at county and watershed for } \\
\text { community planning } \\
\text { - Will nighttime temperatures } \\
\text { also stay elevated? } \\
\text { - Ground temperature and } \\
\text { "ground temperature timing" } \\
\text { "Feels like" temperature is } \\
\text { relevant to people, but less } \\
\text { so for equipment } \\
\text { Solar radiation data on } \\
\text { 15-minute timescales for } \\
\text { wastewater treatment plants }\end{array}$ & $\begin{array}{l}\text { - Show back-casting aligns } \\
\text { with historic observation } \\
\text { to get internal buy-in from } \\
\text { decision makers } \\
\text { - Locations of vulnerable } \\
\text { populations } \\
\text { - Physical characteristics } \\
\text { of neighborhoods } \\
\text { - Demographics of } \\
\text { neighborhoods } \\
\text { - Temperature data } \\
\text { - Daily max min } \\
\text { - Diurnal scale } \\
\text { - Hourly scale } \\
\text { - } 10 \text {-minute scale } \\
\text { To understand power } \\
\text { demand during heat } \\
\text { waves: } \\
\text { W When does load go } \\
\text { up } \\
\text { - How much does load } \\
\text { go up } \\
\text { - At what temperature } \\
\text { - does load go up } \\
\text { Sudden increase in } \\
\text { temperature will increase } \\
\text { load; a sudden decrease } \\
\text { impacts equipment } \\
\text { How long can equipment } \\
\text { withstand higher } \\
\text { temperatures (how many } \\
\text { days of high heat cause } \\
\text { things to break) } \\
\text { expected load of } \\
\text { equipment } \\
\text { - }\end{array}$ & $\begin{array}{l}\text { - Quantitative understanding of } \\
\text { changeable climate on longevity } \\
\text { of concrete, steel and other } \\
\text { building materials } \\
\text { - Heat and air systems that } \\
\text { operate under new climate } \\
\text { conditions } \\
\text { - Solar radiation } \\
\text { - } \quad \text { Microclimate } \\
\text { - American Society of } \\
\quad \text { Heating, Refrigerating and } \\
\text { Air conditioning Engineers } \\
\text { data does not capture } \\
\text { humidity } \\
\text { - Neighborhood-scale } \\
\text { temperatures must align with } \\
\text { building/community needs } \\
\text { Thermodynamic data within tree } \\
\text { canopies: predictions of humidity } \\
\text { and temperature gradients in tree } \\
\text { canopies (to calculate ecosystem } \\
\text { services) } \\
\text { - More detailed information on } \\
\text { extent, intensity, and duration of } \\
\text { extreme events } \\
\text { Aquifer drawdown, recharge data } \\
\text { in real time at the scale of the } \\
\text { aquifer and region } \\
\text { New crops and hybrids adapted } \\
\text { to new climate conditions, } \\
\text { especially variable weather } \\
\text { - Less vulnerable to winter } \\
\text { kill (polar vortex) } \\
\text { Less vulnerable to } \\
\text { dormancy breaks before } \\
\text { the true growing season } \\
\text { (e.g., will not break bud in } \\
\text { February and then be killed } \\
\text { with March freeze) }\end{array}$ & $\begin{array}{l}\text { - To help people adapt and to } \\
\text { promote effective policy, we need } \\
\text { better understanding of how } \\
\text { emotions impact decisions and to } \\
\text { describe impacts in ways that } \\
\text { explain both emotional and } \\
\text { economic impacts (e.g., how } \\
\text { change affects my family as well } \\
\text { as my checkbook) } \\
\text { - Predict human behavioral changes } \\
\text { in how we live inside/outside } \\
\text { - Soft infrastructure that supports } \\
\text { decision-making } \\
\text { - Develop effective education and } \\
\text { awareness programs/tools at the } \\
\text { neighborhood scale and include } \\
\text { nonprofits, planning agencies, } \\
\text { neighborhood organizations } \\
\text { - Industry standards need to } \\
\text { change, and they take } 5 \text { years or } \\
\text { more to develop } \\
\text { - How to evaluate efficacy of } \\
\text { proposed remedies-recognize } \\
\text { quantifying tradeoffs } \\
\text { Understand spatial dependence of } \\
\text { remedy benefits } \\
\text { Understand how infrastructure } \\
\text { assets interact with each other and } \\
\text { how to optimize those interactions, } \\
\text { recognizing assets will respond } \\
\text { differently to climate changes (i.e., } \\
\text { maintaining system resilience) } \\
\text { Good information on how wildfires } \\
\text { will change: frequency, intensity, } \\
\text { character }\end{array}$ \\
\hline
\end{tabular}


TABLE F-7 (Cont.)

\begin{tabular}{|c|c|c|c|c|}
\hline $\begin{array}{l}\text { Type of } \\
\text { Change }\end{array}$ & Currently Available & $\begin{array}{c}\text { Information We Have the } \\
\text { Capacity to Obtain }\end{array}$ & $\begin{array}{l}\text { Information We Are Working on } \\
\text { with Methods under Development }\end{array}$ & $\begin{array}{c}\text { Information That Requires New } \\
\text { Research Directions }\end{array}$ \\
\hline Precipitation & 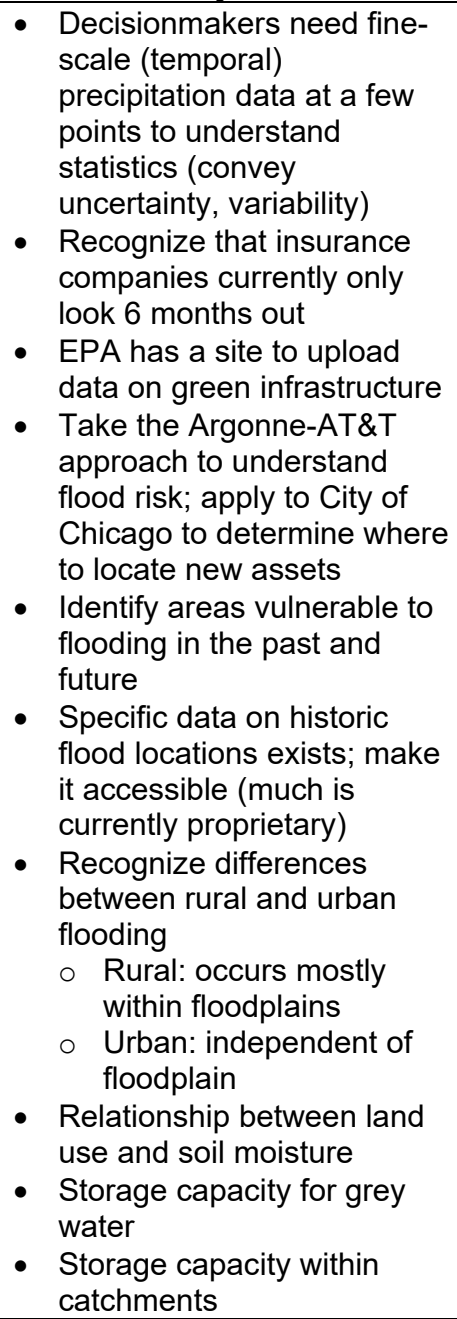 & $\begin{array}{l}\text { - Measure rainfall at very } \\
\text { short timescale } \\
\text { (<15 min.) during } \\
\text { extreme events to better } \\
\text { understand hydrology } \\
\text { - Update floodplain } \\
\text { delineations under } \\
\text { different climate } \\
\text { scenarios } \\
\text { - Determine how return } \\
\text { period (e.g., 100-yr flood) } \\
\text { is changing due to } \\
\text { climate change } \\
\text { Determine where } \\
\text { flooding is due to natural } \\
\text { features (elevation, etc.) } \\
\text { and where it is due to } \\
\text { deficiencies in } \\
\text { infrastructure (bad storm } \\
\text { drains, etc.) } \\
\text { Incorporate the return } \\
\text { period of extreme events } \\
\text { into infrastructure design } \\
\text { Better understand the } \\
\text { lifetime efficacy of green } \\
\text { stormwater infrastructure } \\
\text { Quantify the loss of } \\
\text { permeability of green } \\
\text { stormwater } \\
\text { infrastructure over } \\
\text { time } \\
\text { - Gather accurate } \\
\text { performance data } \\
\text { (e.g., how much water } \\
\text { is it diverting from } \\
\text { onsite systems) }\end{array}$ & $\begin{array}{l}\text { - More nuanced information on } \\
\text { flooding than } 50-\text { or } 100-y r \\
\text { events; instead, provide depth of } \\
\text { flooding and associated } \\
\text { probability } \\
\text { - Real-time extensive, intensive } \\
\text { data on precipitation volume and } \\
\text { intensity (from radar and satellite } \\
\text { imagery) } \\
\text { - New strategies to complete } \\
\text { agricultural fieldwork in window } \\
\text { of time available } \\
\text { O Replace crops } \\
\text { O Aerial technologies that do } \\
\text { not require equipment on } \\
\text { ground } \\
\text { - Tillage changes } \\
\text { Understand impact of urban } \\
\text { farming on water budget and } \\
\text { water flow } \\
\text { Provide precipitation information } \\
\text { at multiple scales (temporal and } \\
\text { spatial) and multiple formats } \\
\text { including soil wetness; include } \\
\text { seasonality }\end{array}$ & 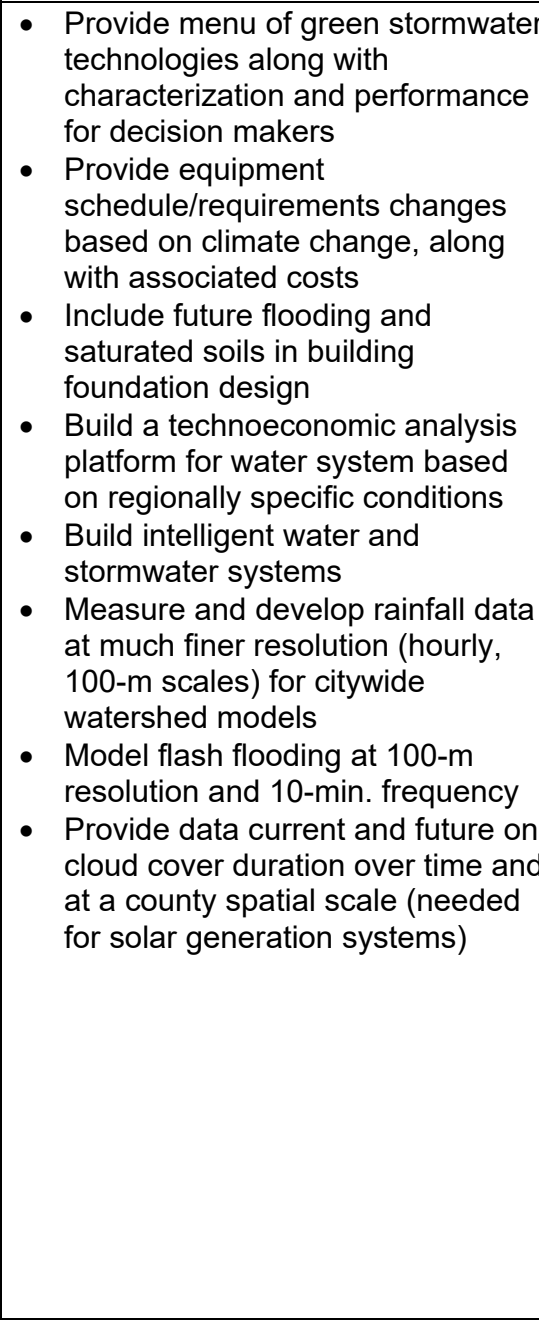 \\
\hline
\end{tabular}


TABLE F-7 (Cont.)

\begin{tabular}{|c|c|c|c|c|}
\hline $\begin{array}{l}\text { Type of } \\
\text { Change }\end{array}$ & Currently Available & $\begin{array}{c}\text { Information We Have the } \\
\text { Capacity to Obtain }\end{array}$ & $\begin{array}{l}\text { Information We Are Working on } \\
\text { with Methods under Development }\end{array}$ & $\begin{array}{c}\text { Information That Requires New } \\
\text { Research Directions }\end{array}$ \\
\hline $\begin{array}{l}\text { Storm and } \\
\text { Wind }\end{array}$ & $\begin{array}{l}\text { - At what thickness of ice, do } \\
\text { power companies start to } \\
\text { have concerns? } \\
1 \text { cm of ice (radial) } \\
\text { causes power lines to } \\
\text { break } \\
\text { Wind exacerbates } \\
\text { breakage } \\
\text { - Understand the link between } \\
\text { conventional weather } \\
\text { variables and ice } \\
\text { accumulation } \\
\text { Currently, meteorologists } \\
\text { have poor predictive } \\
\text { power for ice } \\
\text { accumulation } \\
\text { If power companies } \\
\text { could provide historic } \\
\text { data on ice damage } \\
\text { (date, place), } \\
\text { meteorologists could link } \\
\text { damage with historic } \\
\text { weather variables and } \\
\text { develop predictions for } \\
\text { ice in the future based on } \\
\text { weather in the future } \\
\text { Actions that can be taken to } \\
\text { counteract the negative } \\
\text { impacts of extreme cold } \\
\text { (and snow) on city and utility } \\
\text { emergency response }\end{array}$ & $\begin{array}{l}\text { - Incorporate } \\
\text { trees/greenery into } \\
\text { planning for extreme } \\
\text { events; will best } \\
\text { practices be affected by } \\
\text { climate change? } \\
\text { - Modeling to understand } \\
\text { crop transpiration } \\
\text { - Knowledge of likely crop } \\
\text { damage (urban and } \\
\text { rural) from summer } \\
\text { storms } \\
\text { - Understand duration of } \\
\text { extreme cold (number of } \\
\text { consecutive days below } \\
\text { a specific threshold) } \\
\text { because cold affects } \\
\text { worker safety as well as } \\
\text { power load } \\
\text { Understand future cold } \\
\text { volatility } \\
\text { More accurate wind } \\
\text { speed data for wind } \\
\text { power generation } \\
\text { Wind speed, gusts, } \\
\text { directions at high } \\
\text { temporal and spatial } \\
\text { resolution } \\
\text { - Forecast duration of wind } \\
\text { events } \\
\text { Will peak wind intensity } \\
\text { during winter storms } \\
\text { increase with climate } \\
\text { change? How much and } \\
\text { how often? }\end{array}$ & $\begin{array}{l}\text { - Framework for understanding } \\
\text { limits for adaption to wind and } \\
\text { storms } \\
\text { - Probability of straight-line winds } \\
\text { (derecho winds) under climate } \\
\text { change } \\
\text { - Consortium of interested } \\
\text { institutions providing a } \\
\text { centralized data center on } \\
\text { wind/storm data and forecasts } \\
\text { - Ice information needs } \\
\text { Better forecasting of ice } \\
\text { events so public workers can } \\
\text { pretreat roads } \\
\text { - Where will ice occur } \\
\text { - Will wind be associated with } \\
\text { ice presence } \\
\text { - How much ice (mm) will } \\
\text { accumulate } \\
\text { Accumulation of ice mm/hr on } \\
\text { Roads } \\
\circ \quad \text { Power lines } \\
\circ \quad \text { Trees (with and } \\
\text { without leaves) } \\
\text { Surface temperatures of roads }\end{array}$ & $\begin{array}{l}\text { - Ability to predict hail is of huge } \\
\text { interest } \\
\text { - Model hail frequency in future } \\
\text { climate models } \\
\text { - Provide 30- and 90-day forecasts } \\
\text { of extreme events } \\
\text { - Determine net tradeoff of } \\
\text { preparing for an extreme event vs. } \\
\text { responding to an extreme event } \\
\text { o Number of customers without } \\
\quad \text { power } \\
\text { - Length of time without power } \\
\text { Identify probability of joint extreme } \\
\text { events (e.g., tornado followed by } \\
\text { ice storm) } \\
\text { - Information on snow accumulation } \\
\text { - Liquid equivalent } \\
\text { - Visibility } \\
\text { - If the snow is likely to drift } \\
\text { Definition of driftable snow } \\
\text { Need a metric for drift; understand } \\
\text { the covariance of wind, driftable } \\
\text { snow, and temperature } \\
\text { - Technology to make wastewater } \\
\text { treatment microorganisms more } \\
\text { resilient to cold or novel other } \\
\text { technologies to treat water under } \\
\text { severely cold conditions } \\
\text { Plans for handling polar vortex } \\
\text { events }\end{array}$ \\
\hline
\end{tabular}


TABLE F-7 (Cont.)

\begin{tabular}{|c|c|c|c|c|}
\hline $\begin{array}{l}\text { Type of } \\
\text { Change }\end{array}$ & Currently Available & $\begin{array}{c}\text { Information We Have the } \\
\text { Capacity to Obtain }\end{array}$ & $\begin{array}{c}\text { Information We Are Working on } \\
\text { with Methods under Development }\end{array}$ & $\begin{array}{c}\text { Information That Requires New } \\
\text { Research Directions }\end{array}$ \\
\hline $\begin{array}{l}\text { Storm and } \\
\text { Wind (Cont.) }\end{array}$ & & $\begin{array}{l}\text { - Data on wind within cities } \\
\text { would be useful to } \\
\text { develop wind generation } \\
\text { on top of buildings } \\
\text { o } 100 \text {-yr planning } \\
\text { horizon for big } \\
\text { buildings } \\
\text { - } 20 \text {-yr horizon for roofs } \\
\text { - Align equipment in } \\
\text { prevailing wind direction } \\
\text { - More accurate wind } \\
\text { speed data for wind } \\
\text { power generation } \\
\text { - Determine frequency and } \\
\text { severity of ice storms in } \\
\text { future climate } \\
\end{array}$ & & \\
\hline
\end{tabular}





\section{Argonne}

\section{Environmental Science Division}

Argonne National Laboratory

9700 South Cass Avenue, Bldg. 240

Lemont, IL 60439-4832

www.anl.gov 